Discussion Paper No. 11-053

Innovation Subsidies: Does the Funding Source Matter for Innovation Intensity and Performance? Empirical Evidence from Germany

Dirk Czarnitzki and Cindy Lopes Bento

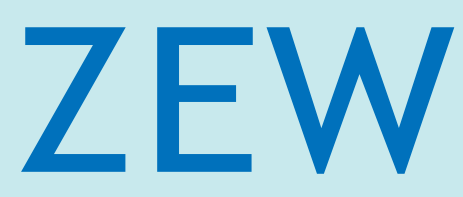

Zentrum für Europäische Wirtschaftsforschung $\mathrm{GmbH}$ Centre for European Economic Research 
Discussion Paper No. 11-053

\section{Innovation Subsidies: Does the Funding Source Matter for Innovation Intensity and Performance? Empirical Evidence from Germany}

Dirk Czarnitzki and Cindy Lopes Bento

Download this ZEW Discussion Paper from our ftp server:

http://ftp.zew.de/pub/zew-docs/dp/dp11053 .pdf

Die Discussion Papers dienen einer möglichst schnellen Verbreitung von neueren Forschungsarbeiten des ZEW. Die Beiträge liegen in alleiniger Verantwortung der Autoren und stellen nicht notwendigerweise die Meinung des ZEW dar.

Discussion Papers are intended to make results of ZEW research promptly available to other economists in order to encourage discussion and suggestions for revisions. The authors are solely responsible for the contents which do not necessarily represent the opinion of the ZEW. 


\section{Non-technical Summary}

It is well-known that $R \& D$ and innovation investments by the private sector suffer from market failure and thus the investment level in the economy is below the social desirable level. It is also a well-known fact that governments of industrialized countries try to correct for such market failure by subsidizing R\&D and innovation. It has been discussed for decades whether those policies are subject to crowding out effects. A topic that did not receive a lot of attention in the literature so far, however, is the fact that many different policies may influence a private investor's decision on R\&D and innovation activities simultaneously. So far, scholars have either evaluated one specific policy instrument or otherwise treatment effects have been derived as averages of different policy interventions.

In this paper, we go one step further and explicitly distinguish between national and European policies. In particular, we are interested in measuring the impact of one specific policy, namely direct subsidies for innovation and R\&D given that this constitutes the main policy instrument in Germany. More precisely, we analyze the relationship between national funding, European funding and the combination of both on innovation input and output using a sample of German firms.

We conduct a multiple treatment effects analysis on the impact that national subsidies compared to, or in combination with, European subsidies have on innovation and R\&D intensity. Furthermore, in order to estimate the impact of these policies on innovation performance, we analyze whether subsidies, and the different combinations of the latter, have an impact on innovation sales, on sales with market novelties or on future patents applications. Since filing patents for subsidized R\&D is often advised by the funding agency, we further analyze whether the filed patents by subsidized firms get more or less forward citations than patents filed in the counterfactual situation of getting no or other subsidies. Positive effects of those treatments, and the awareness of which combination of policy mix (national, European or both) has the highest impact on innovative activity, is a crucial prerequisite for efficient European and national innovation policies.

We find that both EU grants and national grants, as well as the combination of both, lead to higher innovation input in the economy when compared to a situation where these policies would be absent, i.e. the counterfactual where the recipient firms would not be funded. In addition, we find that EU grants compared to national grants have a higher effect on innovation input which can possibly explained by a larger average grant amount. Hence, full crowding out can be rejected for both types of grants. 
With regards to innovation performance, we find evidence that publicly funded firms do not perform worse when compared to a counterfactual where the recipient firms would have the same innovation budgets without receiving subsidies. Keeping innovation investment constant allows us to indirectly conclude that the granted research projects have a similar productivity as purely privately funded projects. In terms of products sold that are new to the market, we find that firms that receive funding from both sources have the highest sales. We further find that firms that do not get subsidies or get subsidies from either one of the sources would yield more sales with market novelties if they would get a top-up from either of the sources. In terms of total innovation sales, we find superiority of national grants when compared to a counterfactual of no grants or receiving EU grants only. In terms of future patent applications, we find that nationally funded firms (only national or in combination with EU funds) are more likely to apply for patents in period $t+1$. In addition, we can conclude that the filed patents were of high quality given that they have on average more forward citations per patent than the patents filed in the counterfactual situation where no grants (or grants from only one source) are received.This finding that national subsidies (and the combination of national and EU subsidies) seem to be successful is reassuring in the light of future German policy programs where the goal is to increasingly deliver public support from the EU through existing national channels. 


\section{Das Wichtigste in Kürze (Summary in German)}

Investitionen in Forschung und Entwicklung (FuE) und Innovation der Wirtschaft sind von Marktversagen betroffen, und daher liegt das tatsächliche unter dem gesellschaftlich wünschenswerten Investitionsniveau. Daher versuchen Regierungen industrialisierter Staaten dieses Marktversagen durch die Vergabe von Subventionen zu korrigieren. Ob solche Politikmaßnahmen Mitnahmeeffekte erzeugen wurden in der Literatur seit Jahrzehnten diskutiert. Ein Thema, dass jedoch bisher weniger Aufmerksamkeit erlangt hat, ist die Tatsache, dass in der Regel eine Vielzahl von Politikinstrumenten Einfluss auf Investitionsentscheidungen von Unternehmen haben. Bisher wurde in der Literatur entweder ein spezifisches öffentliches Förderprogramm evaluiert, oder ein Durchschnittseffekt aus zahlreichen Programmen abgeleitet.

In dieser Studie gehen wir daher einen Schritt weiter, und unterscheiden explizit zwischen Förderinstrumenten der Europäischen Union und nationalen Politiken. Von zentralem Interesse sind direkte projekt-bezogene Subventionen für FuE und Innovation. Wir untersuchen mithilfe einer Stichprobe deutscher Unternehmen den Einfluss von nationalen und Europäischen Fördermaßnahmen, sowie Kombinationen derer, auf den Innovationsaufwand sowie -erfolg. Dazu verwenden wir ein multiples „Treatment“ Analyseverfahren. Als Maße für den Innovationsaufwand verwenden wir die FuE-Intensität und die Innovationsintensität der Unternehmen. Als Erfolgsmaße werden das Patentierungsverhalten, Umsätze mit innovativen Produkten im Allgemeinen sowie Umsätze mit Marktneuheiten. Da Patentanmeldungen häufig von den staatlichen Fördermittelvergabestellen als Signal positiver Forschungsergebnisse erwünscht werden, prüfen wir auch, ob die Patente in einem zukünftigen 5-Jahreszeitraum mehr oder weniger Zitationen erhalten.

Es zeigt sich, dass sowohl EU als auch nationale Fördermittel, sowie die Kombination aus beiden Quellen, zu höherem Innovationsaufwand in den begünstigten Unternehmen führen. Ferner stellt sich heraus, dass EU Mittel höhere Effekte hervorrufen als nationale Quellen. Dies kann möglicherweise durch einen im Durchschnitt höheren Förderbetrag pro Projekt in den EU-Programmen im Vergleich zu nationalen Politiken erklärt werden. Unsere Ergebnisse schließen somit vollkommene Mitnahmeeffekte generell aus.

Im Hinblick auf den Innovationserfolg zeigt die ökonometrische Analyse, dass die geförderten Unternehmen im Allgemeinen nicht weniger gute Ergebnisse erzielen als in einer kontrafaktischen Situation in der keine Fördermittel erhalten worden wären (bei gleichen 
Innovationsbudgets). Dadurch dass in diesem Untersuchungsschritt die Innovationsbudgets konstant gehalten werden, können wir indirekt darauf schließen, dass die geförderten Projekte eine ähnliche Produktivität haben wie rein privat finanzierte. Im Hinblick auf den Umsatz mit Marktneuheiten finden wir, dass Unternehmen, die Fördermittel aus beiden Quellen beziehen, die höchsten Umsätze erzielen. Zusätzlich stellt sich heraus, dass Firmen die keine Fördermittel oder lediglich Mittel aus einer Quelle beziehen mehr Erfolg mit dem Absatz von Marktneuheiten erzielen würden, wenn sie zusätzliche Mittel bekämen. Bei Umsätzen mit innovativen Produkten im Allgemeinen erzielen nationale Fördermittel höhere Erfolge (a) als EU-Gelder (b) im Vergleich zu der kontrafaktischen Situation wenn das gleiche Innovationsbudget rein privat finanziert wäre. Bei den Patentanmeldungen zeigen sich ähnliche Resultate. National geförderte Firmen (entweder Empfänger, die ausschließlich nationale Mittel erhalten, oder solche die sowohl nationale als auch EU-Mittel erhalten) melden mit größerer Wahrscheinlichkeit mehr Patente in der Periode $t+1$ an. Außerdem können wir schlussfolgern, dass die angemeldeten Patente von hoher Qualität sind, da sie im Durchschnitt in der Zukunft mehr Zitationen erhalten als solche Patente, die in der kontrafaktischen Situation angemeldet werden, in der keinerlei Förderung erhalten wurde.

Dieses Ergebnis, dass nationale Förderprogramme (und die Kombination von nationalen und EU-Programmen) erfolgreich $\mathrm{zu}$ sein scheinen, ist im Hinblick auf zukünftige Entwicklungen in der Forschungs- und Technologiepolitik vielversprechend. Das zukünftige Ziel ist stärkere Vernetzung nationaler und Europäischer Maßnahmen durch existierende, länder-spezifische Kanäle. 


\title{
Innovation subsidies: Does the funding source matter for innovation intensity and performance? Empirical evidence from Germany*
}

\author{
Dirk Czarnitzki ${ }^{\mathrm{a}, \mathrm{b}, \mathrm{c}}$ and Cindy Lopes Bento ${ }^{\mathrm{a}, \mathrm{c}, \mathrm{d}}$ \\ a) K.U.Leuven, Dept. of Managerial Economics, Strategy and Innovation, Leuven \\ b) Centre for R\&D Monitoring (ECOOM) at K.U.Leuven \\ c) Centre for European Economic Research (ZEW), Mannheim \\ d) CEPS/INSTEAD, Luxembourg
}

July 2011

\begin{abstract}
Applying a variant of a non-parametric matching estimator, we consider European funding and national funding as heterogeneous treatments, distinguishing and simultaneously analyzing the effect these treatments have on innovation input and performance. In terms of input, getting funding from both sources yields the highest impact. If funding from only one source is received, EU grants have higher effects. In terms of output, holding innovation expenditures constant, funding from both sources display higher sales of market novelties and future patent applications at the firm level. If only one grant is obtained, we find superiority for national funding.
\end{abstract}

Keywords: Subsidies, Innovation, Policy Evaluation, Treatment Effects, Nonparametric matching estimation

JEL-Classification: C14,H50, O38

$\begin{array}{lll} & \text { Dirk Czarnitzki } & \text { Cindy Lopes Bento } \\ \text { Address: } & \text { K.U.Leuven } & \text { CEPS/INSTEAD } \\ & \begin{array}{l}\text { Dept. of Managerial Economics, } \\ \text { Strategy and Innovation }\end{array} & \text { 3 Avenue de la Fonte } \\ & \text { Naamsestraat 69 } & \text { L-4364 Esch sur Alzette } \\ & \text { 3000 Leuven } & \text { Luxembourg } \\ & \text { Belgium } & \\ & & \\ \text { Phone: } & +3216326906 & +352585855-406 \\ \text { Fax: } & +3216326732 & +352585560 \\ \text { E-mail: } & \text { dirk.czarnitzki@econ.kuleuven.be } & \text { cindy.lopesbento@ ceps.lu }\end{array}$

\footnotetext{
* Acknowledgments: Financial support from the Fonds National de la Recherche Luxembourg is gratefully acknowledged. We thank ZEW's MIP team for providing the survey data and Thorsten Doherr for his help in data processing.
} 


\section{Introduction}

Ever since Schumpeter's seminal work, the importance of R\&D and innovation has been widely acknowledged among economic scholars as well as among entrepreneurs and policy makers. As a matter of fact, the technological progress triggered by $R \& D$ and innovation is indispensible for sustained growth and long-term competitiveness. Hence, investment in knowledge is of primary importance to keep economic activity at a sound level.

Despite these broadly accepted facts, investment in $R \& D$ in the business sector suffers generally from market failure (Arrow, 1962). First, the generated knowhow by R\&D activities can spillover to competitors, making it impossible for a company to appropriate all the returns from its initial investment. Second, firms often face financial constraints for R\&D investments due to asymmetric information between the company and potential external investors. Indeed, not only are $R \& D$ investments linked to a high uncertainty about the expected returns, but unlike investment in physical capital, $R \& D$ expenses cannot serve as collateral. Most of the investment goes into wages of R\&D staff and is thus immediately sunk. As a consequence, firms often face credit constraints for $R \& D$ and innovation investment (see Hall and Lerner, 2010, for a recent survey).

These market failure arguments explain why the socially optimal investment level is generally higher than the level of private investment. Indeed, while the social returns to R\&D and innovation can be substantial, the private returns are uncertain. Even though firms cannot appropriate all of their investments, they have to bear all of the costs (Nelson, 1959, Arrow, 1962). With the objective to reduce this gap between the actual private investment and the socially desirable investment as well as in order to ensure national competitiveness and to provide new and improved technology for public sector functions, governments typically subsidize $R \& D$ and innovation activities. In the ideal case, this reduces the price of socially valuable R\&D projects for private investors to a level at which it becomes profitable to invest. Government intervention in business related $R \& D$ is thus justified by market imperfection and is since many years common practice in most industrialized countries. Furthermore, while the use of other policy measures such as e.g. trade and industrial policies is regulated through international agreements, $R \& D$ policies are one of the few remaining sovereign policies that national governments have to influence their industrial activities (Haaland and Kind, 2006). Yet, with the exception of a few countries - including Austria, Germany, Korea and the United States - many OECD countries have responded to financial pressures by cutting their annual budget provisions for research and development (OECD, 2010). 
Even though the European Council stimulated R\&D investments through its "Action Plan 2010" and through the renewed Lisbon Strategy on growth and job creation, Europe lags behind its main competitors, the United States and Japan. While the US spends some $2.8 \%$ of its GDP on R\&D and Japan around 3.4\%, the EU is at a mere 1.8\%, and hence still a long way to go to the formerly foreseen target of $3 \%$ for 2010 (OECD, 2010). To narrow this gap between the EU and some other major economic players, the European Commission supplements national policies by using different mixes of innovation policy instruments to fasten the pace of technological progress. More concretely, it has adopted three main instruments to achieve the goals of the renewed Lisbon Strategy on growth and job creation, namely the 7th Research Framework Program (FP7), the Competitiveness and Innovation Program (CIP) and the Structural Funds. As part of the Structural Fund, the Cohesion Policy alone is spending some $€ 80$ billion on enterprise and innovation support in the current period (2007 - 2013), representing a higher amount than the one spent on transport or human resources, with innovation representing the only field to be a key priority in all Member States.

Due to the remaining gap in public investments in $R \& D$, and because of decreasing European national budgets, it is essential to identify the most efficient way of allocating public money. The key question in assessing a policy mix is whether it is appropriate, efficient and effective. Ideally, a policy mix takes into account possible interactions among instruments (i.e. national subsidies vs. European or other regional subsidies, direct subsidies vs. tax incentives, patent laws, low interest rates etc.) and ensures adapted support for each country's innovation systems, needs and challenges. It is thus fundamental that governments adopt strategies allowing them to choose beneficiaries of public support that are most proficient to achieve the desired results. A better understanding of the impact of policy measures adopted on a national or regional level thus contributes to a more pragmatic assessment of what can realistically be expected of these policies in terms of pace and direction of innovative activities.

In this paper, we are interested in measuring the impact of one specific policy, namely direct subsidies for innovation and R\&D. More precisely, we analyze the relationship between national funding, European funding and the combination of both on innovation input and output using a sample of German firms. Germany appears to be a very appropriate case for this study, as Germany is one of the few European countries that does not maintain policy schemes granting tax credits to $R \& D$ performers, but uses direct subsidies for $R \& D$ performers as a main policy tool. Therefore, the estimated effects of direct subsidies are less 
confounded with other policies in Germany than in other European countries that also grant R\&D tax credits to eligible firms.

We conduct a multiple treatment effects analysis on the impact that national subsidies compared to, or in combination with, European subsidies have on innovation and R\&D intensity. Furthermore, in order to estimate the impact of these policies on innovation performance at the firm-level, we analyze whether subsidies, and the different combination of the latter, have an impact on innovation sales, on sales with market novelties or on future patents filed. Since filing patents for subsidized R\&D is often advised by the funding agency, we further analyze whether patents filed by subsidized firms get more or less forward citations than patents filed in the counterfactual situation of getting no or other subsidies. Positive effects of those treatments, and the awareness of which combination of policy mix (national, European or both) has the highest impact on innovative activity, is a crucial prerequisite for European and national innovation policies to achieve the goal of securing long-term growth, international competitiveness and employment by using public money as concise as possible. To the best of our knowledge, this paper is the first to empirically distinguish and simultaneously analyze national subsidies, European subsidies and the impact the combination of both can have on innovation and R\&D intensity as well as on innovation performance of recipient firms.

The remainder of the paper is organized as follows: section 2 reviews the literature. Section 3 describes the research question, the methodology and the data. Section 4 presents the empirical findings and Section 5 concludes.

\section{This study in the context of existing literature}

For many years now, the impact of R\&D policies on firms' innovation behavior has been of interest in the economic literature. Mostly, researchers were interested in knowing whether public subsidies crowd out private R\&D investment. David et al. (2000) survey micro and macroeconomic studies on the impact of public R\&D subsidies on private $R \& D$ expenditure. One major result of their survey is that in most estimations reviewed, the selectivity of the funded firms into public funding programs is largely ignored. Indeed, recipients of subsidies might be chosen by the government because they are more R\&D intensive or because they represent more promising candidates in succeeding their research projects. In this case, funding becomes endogenous to innovative activity, and its inclusion in a linear regression of e.g. R\&D intensity on government subsidies would lead to a bias. More recent studies addressing the selection bias include Busom (2000), Wallsten (2000), Lach (2002), Czarnitzki 
and Fier (2002), Almus and Czarnitzki (2003), Duguet (2004), González et al. (2005), Hussinger (2008) and Czarnitzki and Lopes Bento (2010). With the exception of Wallsten (2000), most studies exclude total crowding out of private investment through public grants. Indeed, basing himself on a sample of 479 observations and using a 3SLS approach, Wallsten (2000) finds that grants crowd out firm-financed R\&D dollar per dollar in his analysis of the US Small Business Innovation Research (SBIR) program. However, the author does not exclude the possibility that the grants might have had a positive effect on keeping the funded firms' R\&D activities constant, which might not have been possible otherwise. Lach (2002) analyzing crowding out effects in Israeli manufacturing using $\mathrm{DiD}$ and dynamic panel models or Gonzales et al. (2005), analyzing crowding out effects of public funding on firm-funded $R \& D$ in the Spanish manufacturing sector, using simultaneous equation models with threshold, reject total crowding out. Many of the other studies answering the question of how much subsidized firms would have invested in R\&D if they would not have participated in public policy programs by applying matching methods, also exclude total crowding out. Those studies include among others Almus and Czarnitzki (2003), finding that Eastern German firms which received public subsidies increased their innovation activities by about four percentage points; Czarnitzki and Hussinger (2004), evaluating the effect of public R\&D funding on R\&D intensity and patent outcome in Germany; Duguet (2004), focusing on growth of the ratio of firms' R\&D to sales for France; or Czarnitzki and Lopes Bento (2010) in a cross-country comparative evaluation, all reject total crowding out, even though some find evidence of partial crowding out. Most of these studies are based on cross-sectional data and use data from national innovation surveys, often complemented by patent data or R\&D funding data from national authorities (see also Cerulli, 2010, for a recent, comprehensive survey).

However, none of these studies differentiates between national and European subsidies. Usually, a selection between grant applicants is made, and beneficiaries are chosen according to a certain number of criteria. These criteria differ according to whether the subsidy is granted by a government or by the European Commission ${ }^{1}$. Not only do expectations of the suggested projects differ from a purely technical point of view, but administrative and bureaucratic requirements might differ as well, forcing the beneficiaries to keep track of expenses, deliverables, workplans and timetables. This in turn might trigger administrative know-how, vital for the sound management of any successful project. Even though each

\footnotetext{
${ }^{1}$ For further information on public R\&D policies employed by the European Commission and the German government, cf. Appendix A.
} 
government might apply different requirements, the EU applies the same ones to every eligible country. Hence, being able to assess if EU grants further enhance R\&D and innovation intensity and higher $R \& D$ per sales or more patent activity compared to national grants will allow us to shed some light on the success of public policies with respect to European grants and with respect to how these policies could better function hand in hand.

In order to evaluate this effect, we will apply a matching estimator in a multiple treatment setting, analyzing the effects of national and/or European subsidies on R\&D intensity and performance.

\section{Research design, methodology and data}

\subsection{Research question}

In line with the literature, we investigate how different firm characteristics affect companies' participation in public funding schemes, and how this in turn affects R\&D input and innovation performance.We distinguish 4 groups of firms: (i) firms that get no subsidies at all, (ii) firms that get only EU funding, (iii) firms that get only funding from national sources and (iv) firms that get funding from both these sources combined.

Following the methodology by Gerfin and Lechner (2002) allowing for multiple treatments, we consider the receipt of a national subsidy, a European subsidy and both sources as heterogeneous "treatments" in the subsequent analyses. ${ }^{2}$ This allows us to disentangle the effects due to national funding, to European funding and to funding of both these sources. Given our possible combinations of treatment, we can distinguish between the cases of public funding shown in Table 1. First, innovation input is analysed, i.e. we use total innovation intensity as well as R\&D intensity as dependent variables. Second, we are interested in knowing what the effect of (the combination of) subsidies is on innovation performance. More precisely, we estimate whether a treatment leads to higher sales of new products, or to increased patenting activity in the recipient firms. In this second part of the study, we keep the innovation input constant, i.e. we match on the two propensity scores of funding receipt and on innovation input. ${ }^{3}$ This allows testing two hypotheses: on the one hand, we can test, for instance, whether publicly funded firms achieve the same innovation performance as in the

\footnotetext{
${ }^{2}$ See also Czarnitzki et al. (2007) who used that methodology for a multiple treatment effects study on subsidies and R\&D collaborations in Germany and Finland.

${ }^{3}$ If one would not hold innovation input constant, the regressions would obviously suffer from an omitted variable bias. Suppose we find in the first step of the analysis that subsidies trigger more innovation input. Then it would be trivial to investigate whether these firms also achieve more innovation output if the input is not held constant.
} 
counterfactual situation of not being funded. If that would not be the case, we could conclude that the subsidized projects are actually of lower quality or less productive than projects that are conducted from privately financed resources. On the other hand, we can also test whether a certain type of subsidy (EU vs. national) yields higher performance with the same total innovation budget at the firm level. This could hint at differences in selection criteria of the agencies and more successful project management possibly triggered through reporting requirements induced by the funding authorities.

For both exercises, the cases presented in Table 1 are investigated. The cases in italic, namely cases 6,8 and 9 could not be estimated due to data limitations (see the results section below for more details on the methodology and data).

Table 1: Research question

\begin{tabular}{|c|c|c|c|c|c|}
\hline \multirow{6}{*}{ 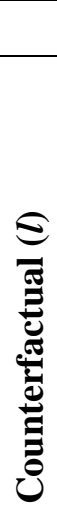 } & D & \multicolumn{4}{|c|}{ Actual status (m) } \\
\hline & & No funding & $\begin{array}{l}\text { Only national } \\
\text { funding }\end{array}$ & $\begin{array}{l}\text { Only EU } \\
\text { funding }\end{array}$ & $\begin{array}{l}\text { Funding from } \\
\text { both sources }\end{array}$ \\
\hline & No funding & & case 1 & case 2 & case 3 \\
\hline & Only national funding & case 7 & & case 4 & case 5 \\
\hline & Only EU funding & case 8 & case 9 & & case 6 \\
\hline & Funding from both sources & case 10 & case 11 & case 12 & \\
\hline
\end{tabular}

Note: The table reads from column to row. E.g., case1: "What would the output of firms that only getnational funding be, if they would not have been funded at all?"; case 4: "Would the output of firms that only get EU funding differ if they only got national funding?"; case 10: "Would a firm that gets no public support spend more on R\&D and innovation if it would get funded from both, the EU and the national government?"

Suppose that there are $M$ different states of treatments and the receipt of one particular treatment $m$ is indicated by the variable $S \in\{0,1, \ldots, M\}$. The average treatment effect of a firm receiving $m$ relative to a firm receiving $l$ (no treatment) can be written as:

$$
E\left(\alpha^{m, l}\right)=\mathrm{E}\left(\mathrm{Y}^{\mathrm{m}} \mid \mathrm{S}=\mathrm{m}\right)-\mathrm{E}\left(\mathrm{Y}^{\mathrm{l}} \mid \mathrm{S}=\mathrm{m}\right)
$$

where $\mathrm{Y}^{\mathrm{m}}$ and $\mathrm{Y}^{1}$ denote the outcome of the different states. Our different treatment categories can take the following different $m$ "values": no funding at all, only national funding, only EU funding, both types of funding. Each of those possible cases involves an estimate of a counterfactual situation, as for firms receiving treatment (meaning firms in $m$ ), we can only observe the actual value of the outcome. However, we cannot observe the 
outcome variable in the counterfactual situation $l$. This counterfactual situation is not observable and thus needs to be estimated. This is defined as the basic problem of causal inference (Holland, 1986).

Estimating $E\left(\alpha^{m, l}\right)$ just by comparing two corresponding sub-samples of firms in state $m$ and $l$ could lead to erroneous results, because one would not have accounted for a potential selection bias. Indeed, as explained in the literature review, subsidized and un-subsidized as well as nationally and European subsidized firms might differ in their characteristics. First, companies themselves choose to apply for public funding. Administrative burden or obligations of publishing some of the findings at the risk of divulging secrecy or free riding by competitors might trigger a certain reluctance against applying for public funding. Second, based on their applications, the funding agencies decide which firms will benefit from public support. As a consequence, neither national nor European funding can realistically be interpreted as a random process. Hence, firms receiving funding might differ from firms not receiving any public support, and firms receiving national support might present different characteristics from firms receiving European aid. It is thus vital that this selection is accounted for when comparing firms in state $m$ with firms in state $l$.

\subsection{Econometric approach}

In econometrics of evaluation literature, different estimation strategies are suggested to correct for selection bias (see Heckman et al., 1999, Imbens and Wooldridge, 2009, for surveys) including the difference-in-difference estimator, control function approaches (selection models), instrumental variable (IV) estimation and non-parametric matching.For the difference-in-difference method, panel data is required with observations before and after (or while) the treatment (change of subsidy status). As our database (to be described in the following subsection) consists of cross-sections of several years, where many firms are observed only once, we cannot apply this estimator. For the application of IV estimators and selection models one needs valid instruments (or an "exclusion restriction" in the selection model case) for the treatment variables. It is very difficult in our case to find possible candidates being used as instruments. Even though our dataset contains a rich set of variables concerning innovative activities, they cannot be interpreted as exogenous to the treatment. Hence, the most appropriate choice is the matching estimator for our data. Its main advantage over IV and selection models is that we neither have to assume any functional form for the outcome equation nor is a distributional assumption on the error terms of the selection equation and the outcome equation necessary. The disadvantage is that it does only control for 
the selection on observables, that is, one assumes that these variables are good proxies of the unobserved factors that might affect your outcome (Rubin, 2008). However, as we discuss in the next subsection, our covariates allow us to assume that we observe all the necessary variables and that as a consequence selection on unobservable effects is unlikely.

Matching estimators have been applied and discussed, among others, by Angrist (1998), Dehejia and Wahba (1999), Heckman et al. (1998a, 1998b), and Lechner (1999, 2000). However, the case considered most frequently in the literature is the one with just one binary treatment. Imbens (2000), Lechner (2001) and Gerfin and Lechner (2002) extend the matching to allow for multiple programs.

Matching isbased on the intuitively attractive idea that a counterfactual situation for companies in state $m$ can be estimated fromthe sample of companies receiving $l$. The matching estimator consists of creating a sample of firms in $l$ that is comparable to the sample of firms in $m$, conditional on a set of a-priori defined characteristics (X). In the empirical application below we denote the estimated sample of state $l$ as matched controls.

The matching estimator is justified by the assumption that the outcome is statistically independent of the treatment. This is the case if the conditional independence assumption (CIA) introduced by Rubin (1977) is respected. Based on appropriate characteristics X, the selection problem is overcome, that is, the samples in states $m$ and $l$ have been balanced with respect to $\mathrm{X}$ and come close to an experimental setting. In this case, one can compare the outcome of the group in state $m$ with the selected control group from state $l$ having similar characteristics in $\mathrm{X}$, and the observed outcome of the selected control group serves as an estimate for the counterfactual situation. Remaining differences in the outcome between both groups can thus be assigned to the treatment. In addition to the CIA, another important precondition for consistency of the matching estimator is common support, i.e. it is necessary that the control group contains at least one sufficiently similar observation for each treated firm. In practice, the sample to be evaluated is restricted to common support. If the overlap between the samples is too small, the matching estimator is not applicable. In other words, for each treatment analysis, the observations with probabilities larger than the smallest maximum and smaller than the largest minimum of all sub-samples defined by $S$ are deleted.

As the matching procedure requires the definition of a set of characteristics $X$, one might run into thecurse of dimensionality problem. Suppose X contains only one variable. It would be intuitive tolook for a control observation in state $l$ that has exactly the same value in $\mathrm{X}$ as the correspondingfirm in $m$. However, if we employ numerous variables in the matching routine, it will become very complicated to find any control observation. Rosenbaum and 
Rubin (1983) have shown that it is sufficient to balance the samples on the propensity score as a single index and thus to reduce the number of variables included in the matching function to just one.The idea is to use the propensity score for each treatment $m$ for the whole sample and find pairs of firms from each sub-sample of interest that have thesame probability of receiving the treatment $m$. In other words, we pair each treated firm with one single non-treated firm, where the pairs are chosen based on the degree of similarity in the estimated probability to participate in a public subsidy scheme (i.e. the probability of receiving national, European or both kind of financial support). Suppose the choice probability of the alternative $\mathrm{j}$ conditional on $\mathrm{X}$ is $P(S=j \mid X=x)=P^{j}(x)$ and we want to calculate the effect of treatment $m$ compared with $l$ on the firms in $m$. Following Gerfin and Lechner (2002), the treatment effect can be calculated by

$$
\begin{array}{r}
E\left(\alpha^{m, l} \mid S=m\right)=E\left(Y^{m} \mid S=m\right)-E\left(Y^{l} \mid S=m\right) \\
=E\left(Y^{m} \mid S=m\right)-E_{p m(X), p l(X)}\left\{E\left[Y^{l} \mid P^{m}(X), P^{l}(X), S=l\right] \mid S=m\right\}
\end{array}
$$

where the first term is replaced by the mean value of the outcome variable of the treated firms in statem, and the second term, the counterfactual situation, is replaced by the mean of the selected control group in state $l$. The average treatment effect is estimated by the mean difference in the outcome of the matched pairs.

The matching protocol is summarized in Table 2 and follows Gerfin and Lechner (2002). In order to obtain the propensity score for our matching routine, we estimate a probit model. More precisely, we specify a seemingly unrelated probit model (also called bivariate dichotomous probit model) on the probability of receiving national funding and European funding. The matching estimator used in this study is a variant of the nearest neighbour matching. We use caliper matching introduced by Cochran and Rubin (1973). The intuition of caliper matching is to avoid "bad" matches (those for which the value of the matching argument $Z_{j}$ is far from $Z_{i}$ ) by imposing a threshold of the maximum distance allowed between the treated and the control group. That is, a match for firm $i$ is only chosen if $\left\|Z_{j}-Z_{i}\right\|$ $<\varepsilon$, where $\varepsilon$ is a pre-specified tolerance.

In order to match on two propensity scores, we calculate the Mahalanobis distance to obtain a one-dimensional measure for the similarity of control observations, as outlined in Table 2. Note that we require the observations on firms in the selected control group $l$ to 
belong to the same year, the same industry and the same region (Eastern versus Western Germany) as the firms in the treatment group $m .^{4}$

\section{Table 2: The matching routine}

Step 1 Specify and estimate a probit model to obtain the propensity scores $\left[\hat{P}^{0}(X), \hat{P}^{1}(X), \ldots, \hat{P}^{M}(X)\right]$.

Step 2 Restrict the sample to common support: delete all observations on treated firms with probabilities larger than the maximum and smaller than the minimum in the potential control group. (This step is also performed for other covariates that are possibly used in addition to the propensity score as matching arguments.)

Step 3 Estimate the counterfactual expectations of the outcome variables. For a given value of $m$ and $l$, the following steps are performed:

a) Choose one observation from the subsample of treated firms and delete it from that pool.

b) Find an observation in the sub-sample of participants in $l$ that is as close as possible to the one chosen in step a) in terms of the propensity scores. Closeness is based on the Mahalanobis distance between this firm and all non-subsidized firms in order to find the most similar control observation. $M D_{i j}=\left(Z_{j}-Z_{i}\right)^{\prime} \Omega^{-1}\left(Z_{j}-Z_{i}\right)$ where $\Omega$ is the empirical covariance matrix of the matching arguments based on the sample of potential controls. Do not remove the selected controls from the pool of potential controls, so that it can be used again.

c) Repeat a) and b) until no observation in $m$ is left.

d) Using the matched comparison group formed in c), compute the respective conditional expectation by the sample mean. Note that the same observation may appear more than once in that group.

Step 4 Repeat step 3 for all combinations of $m$ and $l$.

Step 5 Compute the estimate of the treatment effects using the results of step 4.

Step 6 To estimate the counterfactual situation, we perform sampling with replacement.An ordinary $t$-statistic on mean differences would thus be biased, because it does not take the appearance of repeated observations into account. Therefore, to be able to draw conclusions on statistical inference, we have to correct the standard errors. We follow Lechner (2001) and calculate his estimator for an asymptotic approximation of the standard errors.

\subsection{Data source, variables and descriptive statistics}

\section{Data sources}

The data used in this paper stem from the Mannheim Innovation Panel (MIP), which is the German part of the Community Innovation Survey (CIS). The CIS, launched in 1991 jointly by Eurostat and the Innovation and SME Program, aims at improving the empirical basis for innovation activities at the firm level in the Member States. The CIS covers all EU Member States, Norway and Iceland using a largely harmonized questionnaire throughout participating countries. Thus the data are comparable on the European scale and are based on representative

\footnotetext{
${ }^{4}$ Note that we also experimented with kernel matching in order to reduce the variance of the estimates. However, kernel matching involves a larger bias than nearest neighbour matching. In our application with multiple treatments, kernel matching led to partially imbalanced covariates after the matching. Therefore, we stuck to the nearest neighbour approach, as this allows for a smaller bias at the price of a larger asymptotic mean squared error, though.
} 
samples of firms in the economies. Eurostat presents detailed descriptive survey results for all countries and aggregate statistics. The CIS databases contain information on cross-sections of firms active in the manufacturing sector and in selected business services.

In this study, we analyze the above explained research question for a sample of German firms, using data from several waves of the MIP that contained a question on the receipt of innovation subsidies from the national government and the EU, respectively. Most questions of the MIP are asked such that the survey covers a 3-year period. For instance, the MIP 1995 asks for innovation activities in the period of 1992-1994. A firm would be asked whether it introduced a new product within this 3-year period. In particular, we use the following MIP waves: MIP1995 (covering the years 1992-1994), MIP1999 (covering the years 1996-1998), MIP2001 (covering the years 1998-2000), MIP2003 (covering the years 2000-2002), MIP2004 (covering the years 2001-2003), MIP2005 (covering the years 2002-2004) and MIP2007 (covering the years 2004-2006). Moreover, the data has been complemented by information collected from patent databases.

Our sample concerns only innovative firms and covers manufacturing as well as business related services sectors. According to the Oslo Manual an innovation is defined as the implementation of a new or significantly improved product (good or service), or process, a new marketing method, or a new organizational method in business practices, workplace organization or external relations (see Eurostat and OECD, 2005). Our innovation definition focuses on technological innovation, as mere organizational and marketing innovation projects are usually not subsidized by governments. Thus, an innovator in this study is a firm that either has introduced at least one new or significantly improved product, has introduced a new production process, or has attempted to technologically innovate, that is, the firm may have either abandoned an innovation project or has at least one ongoing innovation project. Table A1 in the appendix shows the industry structure of our sample. In total, the sample consists of 8,734 observations, out of which 6,272 observations did not receive any funding at all, 1,535 received exclusively national funding, 140 received exclusively EU funding and 787 received funding from both financial sources.

Unfortunately, we can use the data only as pooled cross-sections but not as panel. The 8,734 observations correspond to 6,106 different firms, and $73 \%$ of the firms are only observed once in our sample. Thus, panel econometric approaches, such as the difference-indifference estimator, are ruled out as we would lose the lion's share of our sample. 


\section{Dependent variables}

In the first part of this paper, the main question of the analysis is whether firms' innovative activities are stimulated by public innovation subsidies, and by the type of funding they are receiving. Treatments are indicated by two dummy variables: PFEU indicates that the firm is a recipient of a European grant and PFNAT indicates a beneficiary of a national grant. As explained in the introduction, the European Commission adopts a mix of innovation policies in order to remedy to Europe's lagging behind its main competitors. However, in this paper we do not differentiate between the various policies of the EU, but we only compare any European measure vs. any national measure. Of the full sample, $28.2 \%$ of the firms receive some kind of public support. Out of these beneficiaries, 5.7\% receive only European grants, $62.3 \%$ receive only national grants and $32 \%$ receive both $R \& D$ activity is measured as $R \& D$ intensity, $R D \_I N T$, being the ratio of internal $R \& D$ expenditures to sales (multiplied by 100) and total innovation intensity, INNOV_INT, which is the ratio of total innovation expenditure to sales (multiplied by 100). ${ }^{5}$

In the second part of this paper, we are interested in knowing to which extent innovation performance varies according to whether or not firms receive subsidies, and the kind of subsidy received. We measure innovation performance by three different variables. First, we employ a patent dummy indicating whether firm $i$ files at least one patent in year $\mathrm{t}+1$ $\left(P A T \_L E A D \_D\right)$. Second, the intensity of total innovation sales is used. In the MIP survey, firms are asked to indicate what percentage of their total sales is due to new products introduced in the period under review. Products may be either entirely new for the respective firm's main product market or may be products that existed in the market before but are new to the firm's portfolio. The variable is measured as per cent of innovation sales to total sales (TOT_INNO_SALES). Third, we use only the sales due to market novelties as percent of total sales (NOV_SALES). Finally, we are interested in knowing whether filed patents got filed because the invention was of good quality or because this was a requirement of the funding agency. Hence, we evaluate the difference in the average citation per patent between the treated and the control group $\left(A V \_C I T \_P A T\right)$.

\footnotetext{
${ }^{5}$ Total innovation expenditure is defined according to the Oslo Manual (see OECD/Eurostat, 2005) and comprises internal and external R\&D spending, the purchase of machinery and software for innovation projects, purchase of other external knowledge such as patents, licenses and similar intellectual property rights, prototyping and similar preparations for production and market introduction, marketing activities in direct relation with a new product introduction as well as cost for training of employees directly linked to innovation projects.
} 


\section{Control variables}

We use several control variables in our analysis that might have an impact on whether or not a firm receives a subsidy and the origin of the latter as well as on the outcome variables mentioned above. Firm size is measured in terms of employment. As the firm size distribution is skewed, the variable enters in logarithms $(\ln E M P)$. We also allow for a potential non-linear relationship by including $(\ln E M P)^{2}$. The $\log$ of the firm's age $(\ln A G E)$ is included in the analysis as it is often claimed that older firms are more reluctant to pursue innovation. In addition, the government maintains special policy schemes for start-up companies which make the receipt of funding possibly more likely for younger firms.

Further we include a dummy variable capturing whether a firm is part of a group $(G P)$ such as a multinational company or a holding company for instance, and if so, whether or not its headquarters are on national or foreign territory (FOREIGN). The likelihood that firms belonging to a group with the parent company on national territory receive a national subsidy is presumably higher, given that those might be better informed about public subsidy schemes because of network linkages and hence more inclined to apply for them. On similar grounds, national governments might favour firms that are part of a group in their decision making process when choosing beneficiaries because the latter are more likely to benefit from potential spillover effects and specialised know-how from their parents. Similarly, firms belonging to groups with a foreign parent company might be more likely to file applications in their home country or at the EU level. In addition, governments typically maintain special policy instruments for small and medium-sized firms. If a small firm is however majorityowned by a large parent company, it would no longer qualify for most SME-programs and hence the likelihood to receive a subsidy, at least at the national level, is reduced. The dummies GP and FOREIGN thus also control for this type of company profile, and, ex-ante, it is unclear whether one should expect a positive or a negative effect because of the two opposing arguments outlined above.

Furthermore, we also account for capital intensity. As a matter of fact, it is desirable to control for different technologies used in the production process, as capital-intensive production might rely more heavily on innovation activities than labour-intensive firms, and might already have more previous experience in conducting $\mathrm{R} \& \mathrm{D}$ projects. The variable is measured as fixed assets relative to employment $(C A P I N T=$ fixed assets/EMP).

Previous experience in successful R\&D activities plays a vital role when applying for public support, as governments often adopt a picking-the-winner strategy and hence might favour firms with previous success stories. 
Therefore, we include the patent stock $(P S)$ in our regression. The patent stock enters into the regression as patent stock per employee to avoid potential multicollinearity with firm size $(P S / E M P)$. Even though "not all inventions are patentable" and "not all inventions are patented" (Griliches, 1990, p.10), the patent stock is the best approximation we have for past innovation activities as data on previous $R \& D$ expenditures are not available. The patent stock information stem from the EPO dataset and are computed as a time series of patent applications with a $15 \%$ rate of obsolescence of knowledge capital, as is common in the literature (see e.g. Jaffe, 1986; Hall, 1990; Griliches and Mairesse, 1984):

$\mathrm{PS}_{\mathrm{i}, \mathrm{t}}=\mathrm{PS}_{\mathrm{i}, \mathrm{t}-1} \times 0.85+$ patentapplications $\mathrm{i}_{\mathrm{i}, \mathrm{t}}$.

In addition to past successful innovation, the current innovation potential clearly depends on the firm's current ability to engage in R\&D activities. This, as well as administrative knowhow, is controlled for by a dummy taking the value of 1 if a firm has an internal $R \& D$ department $(R D L A B)$.

Furthermore, we include the export intensity $($ EXPORT $=$ sales abroad $/$ total sales $)$ to measure the degree of international competition a firm faces. Firms that are active in foreign markets may be more innovative than the ones serving only nationally and possibly more likely to apply for subsidies.

We also account for the price-cost margin. We approximate it empirically as introduced by Collins and Preston (1969) and Ravenscraft (1983) [PCM = (sales - staff cost - material costs) / sales]. PCM accounts for the availability of internal funds. It has been pointed out in the literature that the major financial resource for innovation projects are internal funds, as firms might suffer from financial constraints in the private credit market. Potential lenders may be less willing to finance $R \& D$ when compared to investments into fixed assets because of the higher uncertainty of returns and lower inside collateral values as R\&D is immediately sunk when expensed (see e.g. Hall and Lerner, 2010, or Czarnitzki and Hottenrott, 2010, for recent surveys of this strand of literature).

Finally, we also include a dummy variable taking on the value of 1 if a firm is based in the Eastern part of Germany (EAST). Eastern German firms benefit from special conditions in terms of public support since Eastern Germanyis subject to the transformation from a planned economy to a market economy after the German re-unification in 1990. Last but not least, industry dummies control for unobserved heterogeneity across sectors (see Table A1 for the definition of industries) and time dummies capture macroeconomic shocks.

As there are missing values for some of the variables, we created dummy variables equal to 1 if the values were missing instead of imputing them with the help of a mean or of 
information from other years. Imputing a zero for the missing values once the dummy is included in the analysis allows us to capture the bias arising from this transformation in the estimated slopes of the concerned variables. This technique has been used to account for missing values in the capital intensity variable $(D(C A P I N T=$ missing $))$ and the $P C M$ variable $(D(P C M=$ missing $))$.

\section{Timing of variables}

As mentioned above, each wave of the survey covers a three-year period. In order to avoid endogeneity between the dependent variables and the covariates to the largest extent, we employ lagged values wherever possible. For instance, suppose the dependent variables are measured in period $t$. Then $\ln E M P, C A P I N T, P S / E M P, P C M$ and EXPORT are measured at the beginning of the survey period, i.e. in $\mathrm{t}-2$.

The information on RDLAB, GP and FOREIGN is only available such that the question covers the whole 3-year period, i.e. t-2 to t. For instance, "Did your firm maintain an own, internal R\&D department during 1996-1998?" We consider AGE as truly exogenous and hence it is measured in period $t$ and the variable EAST is time-invariant.

\section{Descriptive statistics}

Table 3 displays the mean values for all variables for all the envisaged cases of our analysis. In other words, we compare the mean values of unsubsidized firms with the mean values of EU funded firms, of nationally funded firms and of firms that are funded by both funding sources. Furthermore, we compare the means of firms that get exclusively EU funds with firms that get exclusively national funds. As can be seen in Table 3, all of our groups differ significantly among each other in the dependent variables as well as in the covariates. For instance, firms receiving subsidies from both funding sources are on average larger, have more patents per employee, are more likely to have an internal R\&D lab, are younger, more export-oriented, and are more likely to be associated with a group than firms that do not get any subsidies.

These differences are also present when comparing non-subsidized firms with firms that get subsidies only from one funding source (with the exception of age with regard to firms that get only EU funding). When comparing characteristics of firms that get only national funding with firms that get only EU funding, we see that the latter tend to be larger, belonging to a group more often with a foreign parent company and are more export-oriented than the former. They further tend to be older. 
Table 3: Descriptive statistics

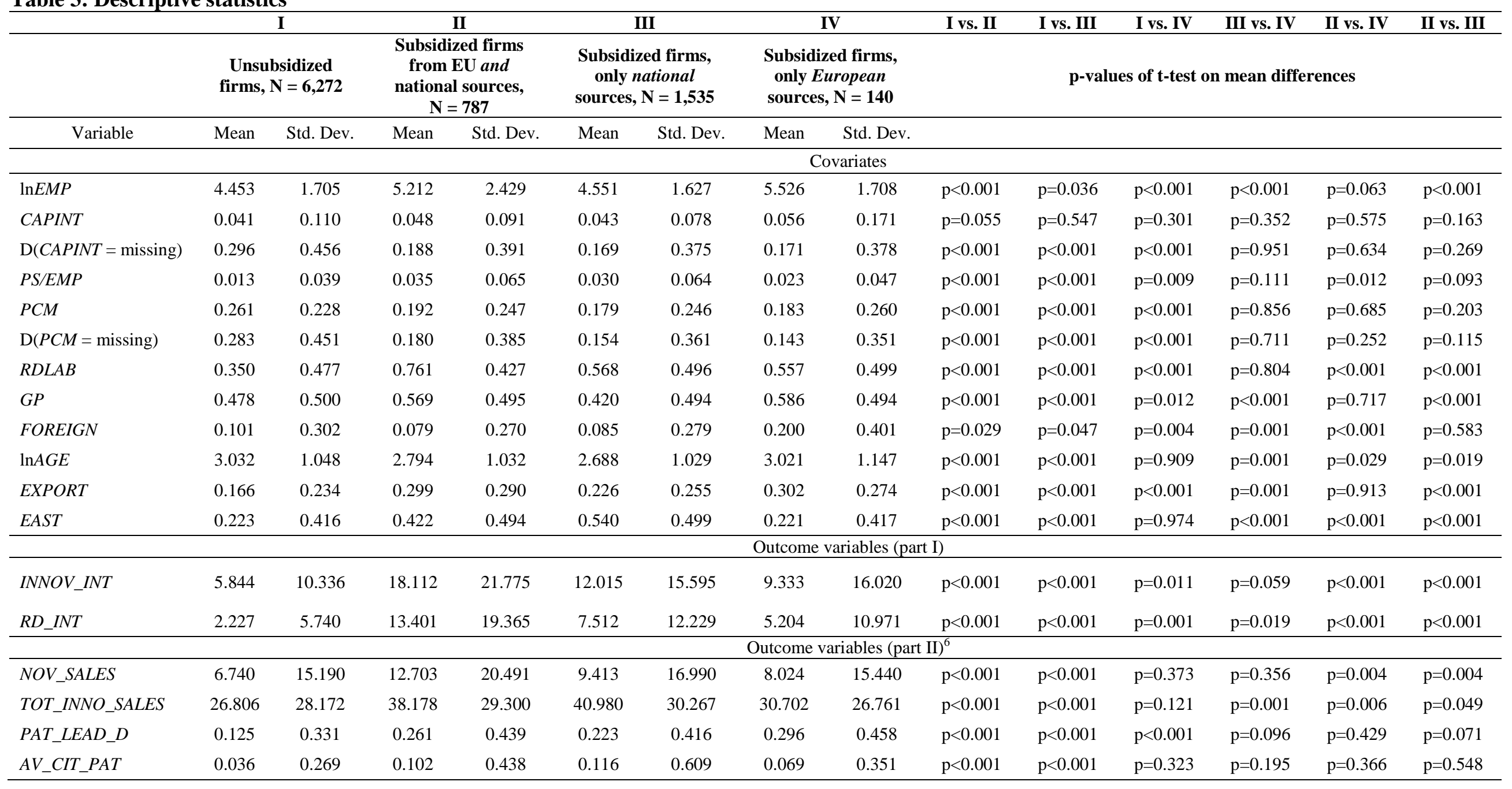

${ }^{6}$ Note that the sample sizes of part II differ from the ones in part I because of some missing values in the four additional outcome variables. In this part the sample sizes correspond to: I: $\mathrm{N}=4,888$, II: $\mathrm{N}=664$, II: $\mathrm{N}=1,246$ and IV: $\mathrm{N}=118$ respectively. 
Some results of the descriptive statistics suggest that public agencies seem to follow a picking-the-winner strategy, as subsidized firms have more experience in innovation activities, have more capacities and capabilities (as approximated by the variables patent stock, firm size and the indicator on having an own internal R\&D department).

The outcome variables, namely internal R\&D intensity and total innovation expenditure, differ significantly between all the cases under review. Compared to unsubsidized groups, the subsidized groups always have higher R\&D and innovation intensity. This also holds for the innovation performance measures that will be used as outcome variables in the second part of the study (with the exception of market novelties in the case of unsubsidized vs. on EU subsidies (I vs. IV) and only national vs. only EU funds (III vs. IV)). Subsidized firms, irrespectively of the source, are also more likely to file patents in the future and their patents have more forward citations, on average The econometric analysis will reveal to what extent these differences can be attributed to the different treatments.

\section{Empirical results}

In order to apply the matching estimator as outlined in the previous section, we first estimate a seemingly unrelated probit model on national and European funding (see Table 4). From this estimation, we obtain the predicted probabilities (the propensity scores) to be employed as matching arguments subsequently.

On first sight, one can conclude from the Probit estimates that basically the same variables are significant in both equations and thus that the European and national agencies have very similar selection criteria. Having a closer look at the magnitude of the coefficients, or more precisely, the differences in magnitudes of the coefficients across equations, we find indeed find indications for different selection behaviours. For instance, the coefficients of the patent stock per employee differ significantly among equations (Wald test: $\chi^{2}(1)=11.40, p$ value $<0.01$ ), that is, the national funding agencies react more sensitively to prior innovation experience than European authorities when selecting recipients. Similarly, the PCM is more important for national funding than for EU funding $\left(\chi^{2}(1)=7.99\right.$, p-value $\left.<0.01\right)$. Thus, national agencies seem to pay more attention to the $R \& D$ capabilities and private financial resources than the European agencies. We do not find significant differences in any other coefficients across equations except for EAST $\left(\chi^{2}(1)=93.29\right.$, p-value $\left.<0.01\right)$, which possibly reflects special national efforts to foster the transformation process in Eastern Germany. Finally, note that the marginal effects of firm size, $\ln E M P$ and its squared term, differ 
somewhat between national and EU funding. The estimated curves describe a U-shaped relationship between the subsidy receipt and firm size. Plotting the estimated probabilities depending on firm size shows that both curves exhibit quite a similar shape until the firm size reaches about 150 employees. Then, however, the EU curve has a steeper slope indicating that firm size after a certain threshold becomes more important for EU funding than for national funding.

Table 4: Seemingly unrelated probit estimations on European $(P F E U)$ and national funding (PFNAT) (8,734 obs.)

\begin{tabular}{|c|c|c|c|c|c|c|}
\hline \multirow{3}{*}{$\ln E M P$} & \multicolumn{3}{|c|}{ PFEU } & \multicolumn{3}{|c|}{ PFNAT } \\
\hline & \multicolumn{2}{|c|}{ Coef. } & \multirow{2}{*}{$\frac{\text { Std. Err. }}{0.046}$} & \multicolumn{2}{|c|}{ Coef. } & \multirow{2}{*}{$\frac{\text { Std. Err. }}{0.039}$} \\
\hline & -0.208 & $* * *$ & & -0.185 & $* * *$ & \\
\hline$(\ln E M P)^{2}$ & 0.037 & $* * *$ & 0.004 & 0.028 & $* * *$ & 0.004 \\
\hline CAPINT & 0.323 & $*$ & 0.169 & 0.152 & & 0.150 \\
\hline$D(C A P I N T=$ missing $)$ & -0.042 & & 0.064 & -0.093 & $*$ & 0.052 \\
\hline$P S / E M P$ & 1.678 & $* * *$ & 0.356 & 2.978 & $* * *$ & 0.325 \\
\hline$P C M$ & -0.281 & $* * *$ & 0.082 & -0.520 & $* * *$ & 0.070 \\
\hline$D(P C M=$ missing $)$ & -0.115 & $*$ & 0.067 & -0.115 & $* *$ & 0.055 \\
\hline$R D L A B$ & 0.467 & $* * *$ & 0.045 & 0.550 & $* * *$ & 0.036 \\
\hline$G P$ & 0.001 & & 0.047 & -0.017 & & 0.038 \\
\hline FOREIGN & -0.200 & $* * *$ & 0.069 & -0.288 & $* * *$ & 0.059 \\
\hline $\ln A G E$ & -0.102 & $* * *$ & 0.022 & -0.086 & $* * *$ & 0.018 \\
\hline EXPORT & 0.484 & $* * *$ & 0.089 & 0.451 & $* * *$ & 0.076 \\
\hline EAST & 0.461 & $* * *$ & 0.046 & 0.923 & $* * *$ & 0.038 \\
\hline Intercept & -1.330 & $* * *$ & 0.183 & -1.151 & $* * *$ & 0.154 \\
\hline $\begin{array}{l}\text { Test on joint significance of industry } \\
\text { dummies }\end{array}$ & \multicolumn{3}{|c|}{$\chi^{2}(11)=97.39 * * *$} & \multicolumn{3}{|c|}{$\chi^{2}(11)=153.84 * * *$} \\
\hline Test on joint significance of time dummies & \multicolumn{3}{|c|}{$\chi^{2}(6)=31.30 * * *$} & \multicolumn{3}{|c|}{$\chi^{2}(6)=99.50 * * *$} \\
\hline$\rho(=$ correlation of equations' error terms) & \multicolumn{6}{|c|}{$0.734 * * *$ (std. err. $=0.015)$} \\
\hline
\end{tabular}

Note: $* * *(* *, *)$ indicates a significance level of $1 \%(5 \%, 10 \%)$.

As expected, the correlation coefficient $\rho$ is significantly different from zero. Indeed, national and European funding are linked to each other. In other words, if an external shock were to augment the probability of getting national subsidies, it would have also an effect on European subsidies. As $\rho$ is positive, a positive shock in the probability of getting a national subsidy would also translate into a positive shock on the likelihood of EU grant receipts.

As explained in the previous section, a necessary precondition for the matching estimator to be applicable is sufficient common support, meaning sufficient overlap between the propensity scores. In the methodology of Gerfin and Lechner (2002) it is natural that for some cases under review (see Table 1) many treated observations have to be dropped, as one searches for controls in sometimes relatively small samples. Confer, for instance, case 1 in 
Table 1. There we have a sample of 1,535 treated observations and we would search in a potential control group of 6,272 observations. We would thus expect that we lose only a few treated observations because of the common support restriction. In contrast, the cases 6,8 and 9 would require searching 787, 6,272 and 1,535 observations in a potential control group of only 140 observations (firms that got only EU funding). As this obviously appears to result in poor matches, these cases cannot be evaluated with our data, and are thus not considered for any further analysis. For the remaining cases, Table 5 lists the size of the treated groups and their respective control groups, as well as the number of treated observations dropped because of the common support restriction and our imposed caliper threshold serving as maximum tolerance. We chose a threshold of 0.1 in order to match as precise and as balanced as possible. With this threshold, all of our covariates are perfectly balanced after the matching. Note however that the matching results were not affected by this. The impact of the various treatments was the same for all tested thresholds, even if we allowed the distance between matched pairs to be larger in order not to lose as many observations as displayed in Table 5 or if we did not impose a maximum distance at all.

Table 5: Observations lost due to common support and the threshold ("caliper") imposed on maximum distance

\begin{tabular}{ccccc}
\hline Case & $\begin{array}{c}\text { Sample size } \\
\text { of treated obs. }\end{array}$ & $\begin{array}{c}\text { Sample size } \\
\text { of control group }\end{array}$ & $\begin{array}{c}\text { \# of observations lost } \\
\text { due to common support } \\
\text { restrictions (in \%) }\end{array}$ & $\begin{array}{c}\text { \# of observations } \\
\text { excluded due to caliper } \\
\text { restriction (in \%) }\end{array}$ \\
\hline 1 & 1,535 & 6,272 & $5(0.3)$ & $132(8.6)$ \\
2 & 140 & 6,272 & $2(1.4)$ & $18(12.9)$ \\
3 & 787 & 6,272 & $45(5.7)$ & $328(41.7)$ \\
4 & 140 & 1,535 & $2(1.4)$ & $50(35.7)$ \\
5 & 787 & 1,535 & $40(5.1)$ & $305(38.8)$ \\
7 & 6,272 & 1,535 & $220(3.5)$ & $842(13.4)$ \\
10 & 6,272 & 787 & $363(5.8)$ & $2,564(40.9)$ \\
11 & 1,535 & 787 & $3(0.2)$ & $624(40.7)$ \\
12 & 140 & 787 & $1(0.7)$ & $74(52.9)$ \\
\hline
\end{tabular}

Note: Cases 6, 8 and 9 have been dropped for further analysis as the control group size (140 obs.) is not sufficient for a meaningful application of the matching estimator.

In order to assess the success of the matching routine as outlined before, we re-estimate a probit model on the respective treatment indicator defined for each case using the matched pairs. If the matching has been successful, one would expect that a test on overall model significance would not reject the null hypothesis that all coefficients in the regression of the treatment indicator on all the covariates are jointly zero. Table A2 in the appendix reports the overall significance of our probit models after the matching for all considered cases. As the 
test statistics point out, the treatment group and the selected control group are all well balanced in the covariates after the matching for all cases considered here.

\subsection{Subsidy effect on $R \& D$ and innovation intensity}

As previously outlined, we pick the nearest neighbour for each firm to be evaluated. Table 6 presents the matching results for our sample. The various cases in Table 6 relate to the cases presented in Table 1. As is shown by the results, all estimated treatment effects are significantly different from zero. Note that we drew a single nearest neighbour for all cases, but 2 and 12. The cases 2, 4, and 12 consider only 140 treated observations. When we drew a single nearest neighbour the results suffered to some extent from small sample sizes. Therefore we also explored the results when drawing two instead of a single nearest neighbour. It turned out that the results improved for cases 2 and 12, i.e., we obtained smaller standard errors. In case 4, however, we found that drawing two neighbours led to significantly worse matches as the control group was not rich enough to supply two close neighbours for several treated firms. Consequently, we drew two neighbours for cases 2 and 12, but stuck to one nearest neighbour for case 4 as for all the remaining cases.

It can be seen in cases 1 to 3 that getting subsidies (be it from national sources, from EU sources or from both sources cumulated) has a positive effect on $R \& D$ and innovation intensity of the recipient firms compared to not getting subsidies at all. For all 3 cases the outcome variables are significant at a $1 \%$ level and the null hypothesis of full crowding out can hence be rejected.

Cases 7 and 10 consider the opposite case, that is, a "treatment on the untreated". These two cases ask the question whether non-subsidized firms would have benefitted from a treatment if they had gotten a subsidy from either national sources or both national and European sources. Here we find significant negative results, i.e. non-funded firms would have indeed invested more into R\&D and innovation if they had gotten public support.

While the above mentioned results are in line with most of the literature discussed in Section 2, we now turn to the more interesting and not yet investigated cases so far, that is, the different impacts of heterogeneous treatments within beneficiaries of different policies. The cases 4 and 5, for instance, benchmark the impact of EU policies compared to national policies. Interestingly, we indeed find treatment effects that are significantly different from zero. In case 4, it turns out that recipients of EU funding invest more into both R\&D and innovation when compared to the counterfactual of receiving a subsidy from national sources. In case 5, a similar result is obtained. When national subsidies are combined with EU money, 
the recipients also invest more than in the counterfactual situation of only getting a national subsidy.

Accordingly, we also find significant treatment effects in cases 11 and 12 where we investigate whether non-recipients would have potentially benefitted from a different treatment. Firms that actually got only national funding would have benefitted from supplemental EU grants with regard to their R\&D and innovation input. Likewise, firms that got only EU funding would have benefitted from additional national grants.

Table 6: Matching results: Subsidy effect on $R \& D$ and innovation intensity

\begin{tabular}{|c|c|c|c|c|c|}
\hline & \multicolumn{5}{|c|}{ Dependent variable: $R \& D$ Intensity $(R \& D$ expenditures/sales $\times 100)$} \\
\hline \multirow{6}{*}{ 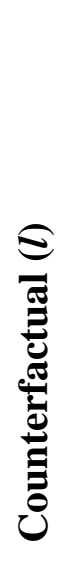 } & & \multicolumn{4}{|c|}{ Actual status (m) } \\
\hline & \multirow{5}{*}{$\begin{array}{l}\text { No funding } \\
\text { Only national } \\
\text { funding } \\
\text { Only EU funding } \\
\text { Funding from both } \\
\text { sources }\end{array}$} & No funding & $\begin{array}{l}\text { Only national } \\
\text { funding }\end{array}$ & $\begin{array}{l}\text { Only EU } \\
\text { funding }\end{array}$ & $\begin{array}{l}\text { Funding from both } \\
\text { sources }\end{array}$ \\
\hline & & & $3.312^{* * *}$ & $\frac{\text { case 2 }}{2.141^{*} *}$ & $8 . \frac{\text { case }}{396} * * *$ \\
\hline & & $-2.140^{* * * *}$ & & $\frac{\text { case 4 }}{3.855^{* *}}$ & $3.895^{* * *}$ \\
\hline & & case 8 & case 9 & & case 6 \\
\hline & & $\frac{\text { case 10 }}{-6.448^{* * *}}$ & $\frac{\text { case } 11}{-4.615^{* * *}}$ & $\frac{\text { case 12 }}{-8.245^{* * *}}$ & \\
\hline \multirow{6}{*}{ 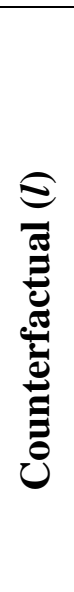 } & \multicolumn{5}{|c|}{$\begin{array}{c}\text { Dependent variable: Innovation Intensity (Innovation expenditures/sales } \times 100 \text { ) } \\
\text { Actual status }(\mathbf{m})\end{array}$} \\
\hline & \multirow{5}{*}{$\begin{array}{l}\text { No funding } \\
\text { Only national } \\
\text { funding } \\
\text { Only EU funding } \\
\text { Funding from both } \\
\text { sources }\end{array}$} & No funding & $\begin{array}{l}\text { Only national } \\
\text { funding }\end{array}$ & $\begin{array}{l}\text { Only EU } \\
\text { funding }\end{array}$ & $\begin{array}{l}\text { Funding from both } \\
\text { sources }\end{array}$ \\
\hline & & & $3 . \frac{\text { case 1 }}{340 * * *}$ & $\frac{\text { case 2 }}{2.959 * *}$ & $8 . \frac{\text { case 3 }}{724 * * *}$ \\
\hline & & $-2 \frac{\text { case } 7}{.734 * * *}$ & & $\frac{\text { case 4 }}{2.782^{* * *}}$ & $\frac{\text { case 5 }}{3.906^{* *}}$ \\
\hline & & case 8 & case 9 & & case 6 \\
\hline & & $\frac{\text { case 10 }}{-6.803^{* * *}}$ & $\frac{\text { case 11 }}{-4.896 * * *}$ & $\frac{\text { case } 12}{-5.501 * * *}$ & \\
\hline
\end{tabular}

Note: Standard errors are in parentheses. *** $(* * *)$ indicates a $1 \%(5 \%, 10 \%)$ significance level. Standard errors are obtained with Lechners (1999) asymptotic approximation correcting for replicated observations due to sampling with replacement.

Acknowledging that public subsidies have an enhancing effect on $R \& D$ and innovation expenditures, comparing the origin of funding allows us to conclude that getting subsidies from both sources combined has the highest effect on $R \& D$ and innovation intensity. Intuitively, this could be expected, as adding together multiple grants results in higher resources for innovative activities. What was however much less clear a-priori, was to know whether subsidies originating from European funds or subsidies originating from national 
funds have a higher effect on $R \& D$ and innovation investment. In case 4 , we find that the EU grants yield higher treatment effects than the national grants. This could have two reasons. Either the EU grants are higher in terms of the size of the amounts distributed, on average, or actually involve different mechanisms within the policy instruments; for instance, the technical and administrative requirements of EU subsidies might be such that only the firms that are most likely to top up the grant with private money more substantially comply. Thus, it could be the case that the EU agencies apply a more effective selection process when grant decisions are taken. In order to investigate whether the R\&D and innovation efforts also differ in productivity among different grant recipients, we now turn to the second part of our research questions where innovation performance is considered.

\subsection{Subsidy effect on innovation performance}

Before presenting the results of the impact of the subsidies on innovation performance, Table 7 summarizes again how many observations are lost because of the common support condition and the caliper threshold. Note that the numbers of the initial sample sizes differ here as we lose some observations because of missing values in the four outcome variables considered in this exercise. We do not just pick one control observation for each treated firm in this setting, but we allow for two controls for each treated firm.

Table 7: Observations lost due to common support and the threshold ("caliper") imposed on maximum distance (innovation performance analysis)

\begin{tabular}{ccccc}
\hline Case & $\begin{array}{c}\text { Sample size } \\
\text { of treated obs. }\end{array}$ & $\begin{array}{c}\text { Sample size } \\
\text { of control group }\end{array}$ & $\begin{array}{c}\text { \# of observations lost due to } \\
\text { common support } \\
\text { restrictions (in \%) }\end{array}$ & $\begin{array}{c}\text { \# of observations excluded } \\
\text { due to caliper restriction }(\text { in } \\
\%)\end{array}$ \\
\hline 1 & 1,246 & 4,888 & $14(1.1)$ & $318(25.5)$ \\
2 & 118 & 4,888 & $2(1.7)$ & $24(23.5)$ \\
3 & 664 & 4,888 & $36(5.4)$ & $360(54.2)$ \\
4 & 118 & 1,246 & $1(0.8)$ & $53(44.9)$ \\
5 & 664 & 1,246 & $29(4.3)$ & $343(51.7)$ \\
7 & 4,888 & 1,246 & $158(3.2)$ & $1,039(21.3)$ \\
10 & 4,888 & 664 & $259(5.2)$ & $2,106(43.1)$ \\
11 & 1,246 & 664 & $2(0.1)$ & $611(49.0)$ \\
12 & 118 & 664 & $2(1.7)$ & $55(46.6)$ \\
\hline
\end{tabular}

Note: Cases 6, 8 and 9 have been dropped for further analysis as the control group size (118obs.) is not sufficient for a meaningful application of the matching estimator.

Table 8 presents the matching results for our sample on innovation performance, proxied by total innovation sales and market novelties, which we measure as the share of innovative products in general (resp. market novelties) sold in terms of total turnover. We further use a 
dummy variable on future patent application as an outcome variable, indicating whether firm $i$ will file at least one patent in year $t+1$ as well as forward citations per patent.

At this stage it is vital to underline that to conduct this estimation we do not only match on the two propensity scores as we did in the previous sub-section, but we also include innovation input, i.e. total innovation intensity which includes $R \& D$ expenditure, as a matching criterion. This is done in order to hold total innovation expenditures constant between the firms in state $m$ and the firms in state $l$. In other words, even if firms get funding from two sources, the firms in the counterfactual group will be chosen such that their total innovation investment is basically the same as the one of the firms in the actual state. The only difference between both groups is hence the criteria they had to fulfil to obtain the one, the other or both grants. As a consequence this allows us to evaluate whether the selection criteria of the funding agencies are such that for a given amount of money invested in innovation projects, the chosen candidates show superior results. If this is the case, one could conclude that those firms have indeed the better $R \& D$ projects as well as the means and experience to successfully accomplish them, and that as a consequence, funding agencies adopt a successful picking-the-winner strategy with regard to the eventual innovation output, and not only the input. As the matching gets somewhat more complex by adding a further matching argument, we set the maximum distance allowed, i.e. the caliper restriction, to a value of 0.3 .

Comparing firms that only get national grants with the counterfactual situation of getting no grant at all (case 1), we do not find any significant result in terms of sales of market novelties or total innovation sales (without differentiating between firm or market novelties). When considering our dummy variable on future patenting, however, we find that nationally funded firms will patent more in year $\mathrm{t}+1$ than in the counterfactual situation with no public support. ${ }^{7}$ We also find that non-recipients would benefit from a national subsidy receipt with regard to future patent applications and total innovation sales (cf. case 7).

When comparing firms that receive only European funding with firms that receive no funding (case 2), we do not find any significant results. However, when comparing firms that got funded from both sources with not funded firms (case 3), we find that the funded firms are significantly more likely to patent in $\mathrm{t}+1$ than their counterfactuals.

\footnotetext{
${ }^{7}$ Even though we do not report these results in a detailed table, if considering patent leads in absolute numbers (and not as a dummy variable), we find that the funded firms will file twice as many patents per 1000 employees than in the counterfactual situation of not receiving subsidies at a significance level of $5 \%$.
} 
Table 8: Matching results: Subsidy effect on innovation performance

\begin{tabular}{|c|c|c|c|c|c|}
\hline \multirow{6}{*}{ 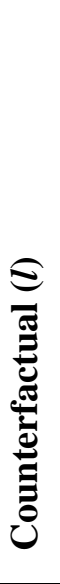 } & \multicolumn{5}{|c|}{$\begin{array}{c}\text { Dependent variable: Sold market novelties }\left(N O V_{-} S A L E S\right) \\
\text { Actual status (m) }\end{array}$} \\
\hline & \multirow{5}{*}{$\begin{array}{l}\text { No funding } \\
\text { Only national } \\
\text { funding } \\
\text { Only EU funding } \\
\text { Funding from } \\
\text { both sources }\end{array}$} & No funding & $\begin{array}{l}\text { Only national } \\
\text { funding }\end{array}$ & Only EU funding & $\begin{array}{l}\text { Funding from } \\
\text { both sources }\end{array}$ \\
\hline & & & $\frac{\text { case 1 }}{-0.448}$ & $\frac{\text { case 2 }}{-1.451}$ & $\frac{\text { case } 3}{0.900}$ \\
\hline & & $\frac{\text { case } 7}{0.102}$ & & $\frac{\text { case 4 }}{-1.948}$ & $\frac{\text { case } 5}{4.544^{*} * *}$ \\
\hline & & case 8 & case 9 & & case 6 \\
\hline & & $\frac{\text { case 10 }}{-3.108^{* *}}$ & $\frac{\text { case 11 }}{-5.060 * * *}$ & $\frac{\text { case 12 }}{-5.787 * *}$ & \\
\hline \multirow{6}{*}{ 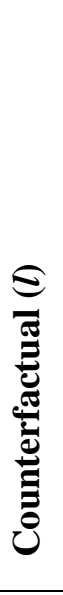 } & \multicolumn{5}{|c|}{$\begin{array}{c}\text { Dependent variable: Sold products that are new to the firm (TOT_INNO_SALES) } \\
\text { Actual status (m) }\end{array}$} \\
\hline & \multirow{5}{*}{$\begin{array}{l}\text { No funding } \\
\text { Only national } \\
\text { funding } \\
\text { Only EU funding } \\
\text { Funding from } \\
\text { both sources }\end{array}$} & No funding & $\begin{array}{l}\text { Only national } \\
\text { funding }\end{array}$ & Only EU funding & $\begin{array}{l}\text { Funding from } \\
\text { both sources }\end{array}$ \\
\hline & & & $\frac{\text { case 1 }}{2.139}$ & $\frac{\text { case 2 }}{-1.982}$ & $\frac{\text { case 3 }}{-2.215}$ \\
\hline & & $\frac{\text { case } 7}{-3.110 * *}$ & & $\frac{\text { case } 4}{-10.574 * *}$ & $\frac{\text { case } 5}{3.211}$ \\
\hline & & case 8 & case 9 & & case 6 \\
\hline & & $\frac{\text { case 10 }}{-3.033}$ & $\frac{\text { case 11 }}{-2.356}$ & $\frac{\text { case 12 }}{-6.686}$ & \\
\hline \multirow{6}{*}{ 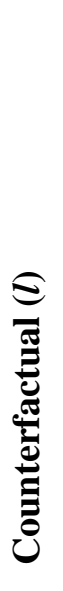 } & \multicolumn{5}{|c|}{$\begin{array}{c}\text { Dependent variable: Patent lead dummy (PAT_LEAD_D) } \\
\text { Actual status (m) }\end{array}$} \\
\hline & \multirow{5}{*}{$\begin{array}{l}\text { No funding } \\
\text { Only national } \\
\text { funding } \\
\text { Only EU funding } \\
\text { Funding from } \\
\text { both sources }\end{array}$} & No funding & $\begin{array}{l}\text { Only national } \\
\text { funding }\end{array}$ & Only EU funding & $\begin{array}{l}\text { Funding from } \\
\text { both sources }\end{array}$ \\
\hline & & & $\frac{\text { case 1 }}{0.046^{* *}}$ & $\frac{\text { case } 2}{0.043}$ & $\frac{\text { case 3 }}{0.070^{* *}}$ \\
\hline & & $\frac{\text { case } 7}{-0.069 * * *}^{* x^{*}}$ & & $\frac{\text { case 4 }}{-0.047}$ & $\frac{\text { case } 5}{-0.015}$ \\
\hline & & case 8 & case 9 & & case 6 \\
\hline & & $\frac{\text { case 10 }}{-0.134^{* * *}}$ & $\frac{\text { case 11 }}{-0.064}$ & $\frac{\text { case 12 }}{-0.088}$ & \\
\hline
\end{tabular}

Note: Standard errors are in parentheses. $* * *(* *, *)$ indicates a $1 \%(5 \%, 10 \%)$ significance level. Standard errors are obtained with Lechner's (1999) asymptotic approximation correcting for replicated observations due to sampling with replacement.

An interesting and rather unexpected result in light of our previous findings is given by case 4. Even though we find in our preceding analysis that firms that get solely EU funds invest more in $R \& D$ and innovation than in the counterfactual situation of getting solely national funds, we do not see a superior innovation performance. When keeping the investment constant, we find a significant negative result in terms of total innovation sales. 
This means that, compared to the counterfactual situation where the firms would receive only national money, they sell less new products in the case of an EU treatment.

When evaluating the treatment effect for firms that get funding from both sources to the counterfactual of only getting national funding (case 5), we only find a positive effect for sales with market novelties.

We find strong evidence that firms would benefit from a combination of EU and national grants with respect to their sales of market novelties, even if they already receive some subsidies (cf. cases 10, 11, and 12). In terms of market novelties, we find that firms that solely get EU funds would also benefit from getting national grants in addition (case 12), and in terms of patent leads that firms not receiving a treatment would benefit from combined support (case 10).

Summarizing the results of this exercise on innovation performance, we can conclude on various aspects. We match on the propensity to receive funding from national and EU sources and also hold the innovation input constant (the total innovation intensity is added as an additional matching criterion). If we consider the evidence on the future patent applications as successful technology developments, it turns out that firms that received funding from national resources (either solely or in combination with an EU grant) patent more than in the counterfactual situation of getting no subsidy. This result is supplemented by the fact that firms not receiving any grant would be more likely to patent if they had received a national grant and those that only got EU funding would be more likely to patent if they had gotten a national grant in addition. As these results are obtained by holding the innovation input constant, and hence firms only differ in the treatment receipt, the analysis suggests that recipients of German national grants actually follow the subsidy guideline: in the major German policy schemes, e.g. the mission-orientated innovation funding, firms are indeed encouraged to utilize their research results by filing patent application, for instance. This implies, in turn, that the funding agencies picked the "right" firms in their selection procedure. If firms are encouraged to apply for patents due to a grant receipt, and we actually find here that this is the case, we can indirectly conclude that the government picked firms that were technologically capable enough to generate patentable inventions as desired by policy makers.

The results on patenting motivated us to explore this innovation output in some more detail. As we stated above, the German government advices firms to utilize their obtained research results. "Utilization" could be best demonstrated by a patent application. Thus, firms may be more likely to patent when the corresponding research was undertaken within a subsidized project. If so, our results on patenting would simply reflect this behaviour and not 
necessarily superior technological developments. In order to investigate this phenomenon further, we collected the number of average forward citations per patent, that is, the number of future applications referring to the patent in question as relevant prior art. Forward citations are typically interpreted as proxy for the "importance", the "quality" or the "significance" of a patented invention. Previous studies have shown that forward citations are highly correlated with the social value (Trajtenberg, 1990) and the private value of the patented invention (Harhoff et al., 1999, Hall et al., 2005). Furthermore, forward citations reflect the economic and technological "importance" as perceived by the inventors themselves (Jaffe et al., 2000) and knowledgeable peers in the technology domain (Albert et al., 1991). ${ }^{8}$

We use the number of citations received in a 5-year window after the filing date as a new dependent variable in our matching analysis. Consider for instance case 1: if we now find that the patents of nationally subsidized firms actually receive lesser citations than in the counterfactual situation of getting no subsidies, it would mean that firms may simply file patents for complying with the advice of the funding agency concerning the utilization of research results without actually displaying superior technological developments to other $R \& D$ projects. If, however, we find that these patents receive more citations, on average, we can conclude that firms are not only more likely to apply for patents in the future, but actually created valuable technology within the funded research projects that otherwise may not have existed.

The results of the citation analysis for our complete set of cases are presented in Table 9. Although not every finding of the patent dummy analysis (cf. Table 8) is confirmed (case 7 is not confirmed), we find evidence that subsidies lead to superior technology developments (cases 1 and 3). In addition, firms that do not get funding could be expected to invent better technology if they were funded by a combination of national and European grants (case 10), all else constant (including the innovation budgets of the firms). We thus conclude that the findings for the patent dummy are not just an indication that firms comply with the public agencies' guidelines, but that they indeed develop valuable technology.

\footnotetext{
${ }^{8}$ See Czarnitzki et al. (2011) for a recent validation of different economic proxy variables derived from patent information.
} 
Table 9: Matching results: average number of forward citations per patent

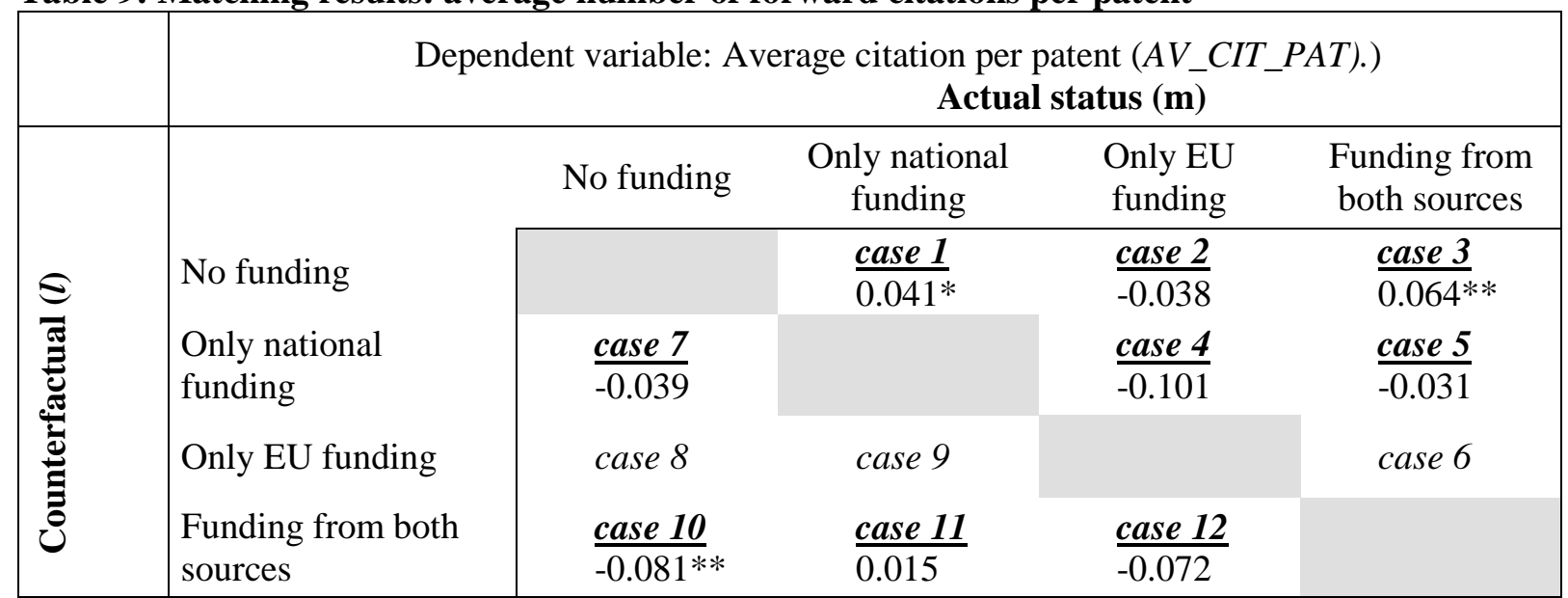

Note: Standard errors are in parentheses. $* * *(* * *)$ indicates a $1 \%(5 \%, 10 \%)$ significance level. Standard errors are obtained with Lechner's (1999) asymptotic approximation correcting for replicated observations due to sampling with replacement.

Our results concerning the two innovation product sales variables are somewhat less informative than the patent analysis (see Table 8). Although we find significant evidence for some cases that we considered, no clear conclusion on successful product implementation can be drawn. To some extent this may not be surprising as we hold the innovation input constant in this analysis. Thus, the good news is that firms funded by either source do not achieve lower product sales when compared to a counterfactual outcome of no or other treatments. We can thus conclude that subsidized $R \& D$ projects are not less productive than purely privately financed projects. These findings are in line with Czarnitzki and Hussinger (2004), Czarnitzki and Licht (2006) as well as Hussinger (2008).

However, we do not find clear evidence that firms would introduce more successful products with the same innovation budgets when their innovation process is guided by certain criteria that have to be respected when public money is received, e.g. systematic accounting of expenses which might increase the process efficiency within organization, systematic reporting duties which might influence the project management positively or may increase the focus of the corresponding innovation efforts and so forth. Of course, our data may not allow identifying such long-term innovation success because of the cross-sectional nature of our data. While we were able to use leads of the patent activity, the data on product sales does not allow for enough time from innovation input to output. Basically we control for innovation budget in period $t$ and relate public funding in a three year period $(\mathrm{t}-2$ to $\mathrm{t})$ to the innovation performance in period t. Although the innovation input in period t may proxy past innovation to a satisfactory extent, it could still be the case that the innovation performance in terms of 
sales only evolves after longer time lags which we cannot take into account with the given data.

Between not funded firms and EU funded firms, our estimation did not yield any significant results for any of the three performance variables. Comparing national and EU funding though, we did find significant superiority of nationally funded firms compared to EU funded firms in terms of total innovation sales.

The reason why we do not find any superior project outcome because of EU policy might be a reflection of different policy priorities in EU and national programs (see a more detailed program description Appendix A). The Cohesion Fund, which encompasses the largest investment of the three main EU instruments, has as a main objective the "Convergence Objective", consisting of getting depressed German regions up to the German and EU standards, in order to get all the regions to successfully compete on the internal market. Hence, the goal of this policy is not a "picking-the-winner" one, but rather an "aiding-thepoor" one. In this light, our results are actually good news for such policy programs. The recipient firms do not lag behind other firms in terms of innovation performance. The second largest EU tool consists in the framework program. As explained in appendix 2, many of the framework activities consist in promoting researchers' mobility, networking activities and other "soft skills" development. As a consequence, the results might not be measurable (at least not in the short run) in terms of market output or patent activities. However, even if these projects trigger less private benefits they might exhibit larger longer term impacts as well as larger social benefits than the national investments. Our findings that EU grants stimulate larger R\&D and innovation investment, hence seem to be in line with the pursed objectives of the respective funding agencies.

\section{Conclusions}

This paper analyses the impact of different types of subsidies on $R \& D$ expenditures and total innovation intensity as well as on innovation performance. Unlike most other related studies in the literature, where the main interest is evaluating whether one faces crowding out of private investment through public support, we evaluate what the impact of national vs., or in combination with, European subsidies are on our outcome variables. Indeed, evaluating national subsidies in isolation of EU subsidies could be erroneous and could trigger misleading conclusions. Given that implementing bodies of EU instruments exist at different levels (supranational, national, sub-national), policy programs are governed by different logics (e.g. excellence vs. cohesion) and mix with national policies, estimating actual policy 
coherence and impacts appears to be a major challenge. Hence, EU Member States try to combine national and EU policies in the most efficient way in order to close the gap between Europe and some of its main competitors in terms of innovation investment and in terms of catching up on technological progress.

In order to evaluate the impact of the current policy mix in the most accurate way, we employ caliper matching to firm level data from Germany to account for a potential selection bias. Matching on two propensity scores, we analyze 9 out of 12 different possible cases of grant combinations. Our main finding is that both EU grants and national grants, as well as the combination of both, lead to higher innovation input in the economy when compared to a situation where these policies would be absent, i.e. the counterfactual where the recipient firms would not be funded. In addition, we find that EU grants compared to national grants have a higher effect on innovation input which can possibly explained by a larger average grant amount. Hence, full crowding out can be rejected for both types of grants.

With regards to innovation performance, we find evidence that publicly funded firms do not perform worse when compared to a counterfactual where the recipient firms would have the same innovation budgets without receiving subsidies. Keeping innovation investment constant allows us to indirectly conclude that the granted research projects have a similar productivity as purely privately funded projects. In terms of products sold that are new to the market, we find that firms that receive funding from both sources have the highest sales. We further find that firms that do not get subsidies or get subsidies from either one of the sources would invest more if they had a top-up from the other source. In terms of total innovation sales, we find superiority of national grants when compared to a counterfactual of no grants or EU grants. However, when interpreting our results, one has to bear in mind that given the short lag between the receipt of a subsidy and the development of a new product imposed by our data, it is possible that the economic contribution of some innovations may not yet have fully materialized.

In terms of future patents filed, we find that nationally funded firms (only national or in combination with EU funds) are more likely apply for patents in period $t+1$. This finding that national subsidies (and the combination of national and EU subsidies) seem to be successful is not only reassuring in the light of current policy tools, but also in the light of future policy projects. Indeed, the objective in Germany is to increasingly deliver public support from the EU through existing national channels. This is at least the case for the investment stemming from the cohesion fund, which is the most important one and where the goal is linking the structural funds closer to the national policy in the future in order to use it rather as an 
additional support of national funding than as a complement to the latter (see Taylor et al., 2000, for more details on Structural Fund Project Decision-Making Systems). Given our findings, we can conclude that this approach seems to be a promising one. In addition, we can conclude that in case of German funding, the agencies picked the firms able to comply with the requirement to utilize their research results, e.g. by filing patents. Evaluating the average forward citations per patent in a 5-year window allows us furthermore to conclude that they do not only patent because it is advised by the funding authorities, but that their technological developments are of high quality.

For future research, it would be useful to have access to more complete panel data, allowing for more time between innovation input and the potential innovation output in order to evaluate the effectiveness of the additional innovation input triggered by subsidies from different sources. Furthermore, it would be interesting to have more detailed information of the respective selection processes of national and European beneficiaries in order to be able to draw more precise conclusions from the econometric results. Ideally, the synergy, complementarity or supplementary of these policies should be estimated at the regional level, preferably by type of company or type of beneficiary. In a similar vein, having data allowing to do a similar exercise but differentiating between the various EU policy instruments could help to further clarify the efficiency and utility of the current policy mix. For instance, the cohesion policy and the framework programs have different goals and we were not able to distinguish between those programs with the data at hand. 


\section{References}

Albert, M.B., D. Avery, F. Narin, and P. McAllister (1991), Direct Validation of Citation Counts as Indicators of Industrially Important Patents. Research Policy 20: 251-259.

Almus, M. and D. Czarnitzki (2003), The effects of public R\&D subsidies on firms' innovation activities: the case of Eastern Germany, Journal of Business and Economic Statistics 21(2), 226-236.

Angrist, J.D. (1998), Estimating the labor market impact of voluntary military service using social security data, Econometrica 66, 249-288.

Arrow, K.J. (1962), Economic welfare and the allocation of resources for invention, in: R.R. Nelson (ed.), The rate and direction of inventive activity: economic and social factors, Princeton, N.J.: Princeton University Press, 609-625.

BMBF (2010), Bundesbericht Forschung und Innovation, Bonn.

Busom, I. (2000), An empirical evaluation of the effects of R\&D subsidies, Economics of Innovation and New Technology 9(2), 111-148.

Cerulli, G. (2010), Modelling and measuring the effect of public subsidies on business R\&D: a critical review of the economic literature, Economic Record 86, 421-449.

Cochran, W.G. and D.B. Rubin (1973), Controlling Bias in Observational Studies: A Review, Sankhya, Ser. A 35, 417-446.

Collins, N. and L.E. Preston (1969), Price-Cost Margins and Industry Structure, Review of Economics and Statistics 51, 271-286.

Czarnitzki D., B. Ebersberger and A. Fier (2007), The Relationship between R\&D Collaboration, Subsidies and R\&D Performance: Empirical Evidence from Finland and Germany, Journal of Applied Econometrics 22(7), 1347-1366.

Czarnitzki, D. and A. Fier (2002), Do innovation subsidies crowd out private investment? Evidence from the German Service Sector, Applied Economics Quarterly (Konjunkturpolitik) 48(1), 1-25.

Czarnitzki, D. and H. Hottenrott (2010), Financing Constraints for Industrial Innovation: What do we know?, Review of Business and Economics 55(3), 346-362. 
Czarnitzki, D. and K. Hussinger (2004), The Link between R\&D Subsidies, R\&D Spending and Technological Performance, ZEW Discussion Paper No. 4-56, Mannheim.

Czarnitzki, D., K. Hussinger and C. Schneider (2011), Wacky patents meet economic indicators, forthcoming in Economics Letters.

Czarnitzki, D. and G. Licht (2006), Additionality of Public R\&D Grants in a Transition Economy: The Case of Eastern Germany, Economics of Transition 14(1), 101-131.

Czarnitzki, D. and C. Lopes Bento (2010), Evaluation of public R\&D policies: A crosscountry comparison, CEPS/INSTEAD discussion paper, Luxembourg.

David, P.A., B.H. Hall and A.A. Toole (2000), Is public R\&D a complement or substitute forprivate R\&D? A review of the econometric evidence, Research Policy 29(4-5), 497529.

Dehejia, R.H. and S. Wahba (1999), Causal effects in nonexperimental studies: reevaluating the evaluation of training programs, Journal of the American Statistical Association 94, 1053-1062.

Duguet E. (2004), Are R\&D subsidies a substitute or a complement to privately funded R\&D? Evidence from France using propensity score methods for non experimental data, Revue d'EconomiePolitique 114(2), 263-292.

Gerfin M. and M. Lechner (2002), A Microeconometric Evaluation of Active Labour Market Policy in Switzerland, The Economic Journal 112, 845 -893.

González, X., Jaumandreu, J. and Pazó, C. (2005), Barriers to innovation and subsidy effectiveness, RAND Journal of Economics 36(4), 930-949.

Griliches Z. (1990), Patent Statistics as Economic Indicators: A Survey, Journal of Economic Literature XXVIII, 1661-1707.

Griliches Z and J. Mairesse (1984), Productivity and R\&D at the firm level, in: $R \& D$, Patents and Productivity, Griliches Z (ed.). University of Chicago Press: Chicago, IL; 339-374.

Haaland, J. and H.J. Kind (2006), Cooperative and Non-cooperative R\&D Policy, Review of World Economics 142(4), 720-745.

Hall, B.H. (1990), The impact of corporate restructuring on industrial research and development, Brooking Papers on Economic Activity (1), 85-136. 
Hall B.H., A. Jaffe, M. Trajtenberg (2005), Market Value and Patent Citations, RAND Journal of Economics, 36, 16-38.

Hall, B.H. and J. Lerner (2010), The financing of R\&D and innovation, in: B.H. Hall and N. Rosenberg (eds.), The handbook of the economics of innovation Vol. I, Amsterdam: Elsevier, 609-639.

Harhoff, D., F. Narin, F.M. Scherer, and K. Vopel (1999), Citation Frequency and the Value of Patented Innovation, Review of Economics and Statistics 81(3), 511-515.

Heckman, J.J., H. Ichimura and P. Todd (1998a), Matching as an econometric evaluation estimator, Review of Economic Studies 65(2), 261-294.

Heckman, J.J., H. Ichimura, J.A. Smith and P. Todd (1998b), Characterizing selection bias using experimental data, Econometrics 66, 1017-1098.

Heckman, J. J., R. J. Lalonde and J. A. Smith (1999), The economics and econometrics of active labour market programs, in: A. Aschenfelter and D. Card (eds.), Handbook of Labour Economics, Amsterdam, 3, 1866-2097.

Holland, P.W. (1986), Statistics and Causal Inference, Journal of the American Statistical. Association 81, 945-960.

Hussinger, K. (2008), R\&D and Subsidies at the Firm Level: An Application of Parametric and Semi-Parametric Two-Step Selection Models, Journal of Applied Econometrics 23, 729-747.

Imbens, G.W. (2000), The role of the propensity score in estimating dose-response functions, Biometrika 87, 706-710.

Imbens, G.W. and J.M. Wooldridge (2009), Recent Developments in the Econometrics of Program Evaluation,Journal of Economic Literature 47, 5-86.

Jaffe, A.B. (1986), Technological opportunity and spillovers of R\&D: evidence from firm's patent, profits, and market value, American Economic Review 76 (5), 984-1001.

Jaffe, A.B., M.S. Fogarty, M. Trajtenberg (2000), Knowledge Spillovers and Patent Citations: Evidence from a Survey of Inventors, American Economic Review 90, 215-218.

Lach, S. (2002), Do R\&D subsidies stimulate or displace private R\&D? Evidence from Israel, Journal of Industrial Economics 50(4), 369-390. 
Lechner, M. (1999), Earnings and employment effects of continuous off-the-job training in East Germany after reunification, Journal of Business and Economics Statistics 17, 74-90.

Lechner, M. (2000), An evaluation of public sector sponsored continuous vocational training in East Germany, Journal of Human Resources 35, 347-375.

Lechner, M. (2001), Identification and Estimation of Causal Effects of Multiple Treatments under the Conditional Independence Assumption, in M. Lechner and F. Pfeiffer (eds.), Econometric Evaluation of Labour Market Policies, Physica, Heidelberg, 43-58.

Nelson, R.R. (1959), The Simple Economics of Basic Scientific Research, Journal of Political Economy 49, 297-306.

OECD/Eurostat (2005), Guidelines for Collecting and Interpreting Innovation Data - the Oslo Manual, $3^{\text {rd }}$ edition, Paris.

OECD (2010), OECD Science, Technology and Industry Outlook 2010, Paris.

Ravenscraft, D.J. (1983), Structure-Profit Relationships at the Line of Business and Industry Level, Review of Economics and Statistics 65, 22-31.

Rosenbaum, P.R. and D.B. Rubin (1983), The central role of the propensity score observational studies for causal effects, Biometrica 70, 41-55.

Rubin, D.B. (1977), Assignment to treatment group on the basis of covariate, Journal of Educational Statistics 2, 1-26.

Rubin, D.B. (2008), For objective causal inference, design trumps analysis, The Annals of Applied Statistics 2(3), 808-840.

Schwab, O. (2010), Expert Evaluation Network-Delivering Policy Analysis on the Performance of the Cohesion Policy 2007-2013, IFS, Germany.

Taylor, S., J. Bachtler and M.L. Rooney (2000), Implementing the New Generation of Programmes: Project Development, Appraisal and Selection, Glasgow, United Kingdom.

Trajtenberg, M. (1990), A Penny for your Quotes: Patent Citations and the Value of Innovations, The RAND Journal of Economics 21(1), 172-287.

Wallsten S.J. (2000), The effects of government-industry R\&D programs on private R\&D: the case Small Business Innovation Research Program, RAND Journal of Economics 31(1), 82-100. 


\section{Appendix A: Main characteristics of European and national policy instruments ${ }^{9}$}

Three main instruments have been developed by the European Commission to contribute to competitiveness and the achievement of the goals of the renewed Lisbon Strategy for Growth and Jobs, namely the 7th Research Framework Programme (FP7), the Competitiveness and Innovation Programme (CIP) and the Cohesion Fund (Structural Funds). These three instruments have as a goal to complement each other in order for Europe to become a knowledge-based economy, "producing knowledge through research, diffusing it through education, and applying it through innovation” (Spring 2005 European Council). The EU's FP7 and CIP support national and cross-border research and innovation projects both within the EU as well as between the EU and certain non-EU countries and regions. The FP7 concentrates on research areas where European cooperation is of particular importance. The CIP encompasses a broad spectrum of research activities to promote competitiveness and innovation, such as the formation of innovation networks, the comparison of innovation policies in EU Member States (benchmarking), venture capital financing, and the funding of innovation projects. The Cohesion Fund has as a main objective to help depressed regions to live up to average European standards.

\section{The European Cohesion Policy}

Comprising 27 Member States, 271 regions and no less than 493 million citizens, the European Union invests in thousands of projects across all over Europe's regions to promote economic and social cohesion by reducing still existing disparities. The main tool to achieve this objective is the European Regional Development Fund (ERDF) and the European Social Fund (ESF), otherwise known as the Structural Funds as well as the Cohesion Fund. With a total budget of $€ 347$ billion for the period 2007-2013, the Cohesion Policy is the single largest source of financial support at EU level, designed to enable all regions to compete effectively in the internal market.

\footnotetext{
${ }^{9}$ The «stylized facts » of this appendix stem from various reports, all of which can be found online. Hence, for further details, cf. http://ec.europa.eu/regional_policy/, http://ec.europa.eu/regional_policy/atlas2007/germany/index_en.htm, $\quad$ http://ec.europa.eu/social/, http://ec.europa.eu/research/index.cfm?pg=reports, http://ec.europa.eu/regional_policy/sources/docgener/evaluation/pdf/eval2007/country_reports/germany.pdf, http://ec.europa.eu/cip/eip/innovation/index en.htm.
} 


\section{European Cohesion Policy in Germany}

Channeled through the Structural Funds, the Cohesion Funds investments have supported a large number of investments in Germany. Over the period 2000-2006, over 1.500 small and medium-sized enterprises (SMEs) received direct investment support and about 800 business start-ups received initial funding. Several thousands of research jobs were created thanks to Cohesion Fund investment in R\&D. Saxony alone received some $€ 230$ million for university and research centre support, enhancing the competitiveness of the region.

For the period 2007-2013, Germany has been allocated $€ 26.4$ billion in total, including about $€ 8$ billion for R\&D and innovation. The largest part of this investment ( $€ 16.1$ billion) goes into the Convergence Objective. The latter comprises regions of low GDP and employment. Hence, the most important part of the funds is directed to depressed regions, in order to raise their competitiveness at the national and at the European level. Indeed, while Germany performs rather well at the national level (GDP per capita is $16 \%$ higher than EU-average), there are still some discrepancies at the regional level. The GDP in Brandenburg for instance is only $76 \%$ of the EU-average, while Hamburg's GDP is $92 \%$ above that average. Nowadays, some 15.3 million citizens live in “Convergence Regions" in Germany. The Regional Competitiveness and Employment Objective ( $€ 9.4$ billion) is applicable to the other regions (the remaining $€ 0.8$ billion go under the European Territorial Cooperation Objective). With respect to the policy mix, the development of the "Enterprise Environment" is the cornerstone for regional development for both Objectives. In terms of $R \& D$ and innovation, some $€ 2.9$ billion are invested through the Convergence Objectives and some $€ 1.5$ billion through the Competitiveness Objective (Schwab, 2010).

\section{The European Framework Programme}

The $6^{\text {th }}$ Framework programme (FP6, covering the period 2002-2006, having a total budget of $€ 19.2$ billion, respectively 4\% of EU Member States' combined public R\&D support) made a total of 213 Calls for Proposals, attracting 56,000 proposals involving 390,000 potential participants and awarded some 10,000 contracts to 74,000 participants. Compared to the $5^{\text {th }}$ Framework Programme (FP5, covering the years 1998-2002), the instruments employed in the FP6 led to fewer but bigger projects. On average, the number of participants per contract doubled between FP5 and FP6. Compared to FP5, the success rate fell in FP6. 
FP7, with a total budget of $€ 50.5$ billion, runs between 2007 and 2013. FP7 is composed of four different specific programs (+ the Euratomprogramme): (1) Cooperation (64.1\% of the total budget), (2) Ideas (14.9\% of the total budget), (3) People (9.4\% of the total budget) and (4) Capacities $\left(8.1 \%\right.$ of the total budget). ${ }^{10}$ In the three years $2007-2009,170$ calls for proposals were concluded, eliciting 55,379 proposals, of which 41,474 passed the formal eligibility criteria (or the $1^{\text {st }}$ stage of two-stage calls). Success rates have slightly risen between 2007-2009, from just over a fifth to just under a quarter in terms of retained proposals.

\section{The Framework Programme in Germany}

The number of retained proposals for funding in 2009 varies according to the programmes. In total, 2,186 applications were received by Germany, out of which 1,198 were retained for funding. 697 of these retained applications fall under the program Cooperation, accounting for a total budget of $€ 0.6$ billion; 58 proposals fall under the Ideas programme accounting for $€ 66$ million; 236 proposals fall under People for an amount of $€ 97$ million; and 189 under Capacities for an amount of $€ 84$ million. The remaining 18 retained proposals fall under the Euratom programme for an amount of $€ 3$ million.

\section{The Competitiveness and Innovation Programme (CIP)}

The CIP, with a total budget of approximately $€ 3.6$ billion for 2007-2013, assures specific Community support programs and relevant parts of other Community programs in fields that are critical to boost European productivity, innovation capacity and sustainable growth. The CIP has been developed in order to tackle both, technical as well as non-technical issues. Furthermore, the CIP covers market replications of existing technologies that are to be utilized in a new and innovative way. If technological solutions have to be validated during the market replication phase of an otherwise already demonstrated technology, projects can be covered by both, CIP and FP7. Most European innovation support measures under the CIP with the exception of the financial instruments and the business support services provided by

\footnotetext{
${ }^{10}$ The four objectives "cooperation, ideas, people and capacities" have following more detailed goals: (1) Gain leadership in key scientific and technology areas by supporting cooperation between universities, industry, research centers and public authorities across the European Union as well as with the rest of the world.; (2) Stimulate the creativity and excellence of European research through the funding of "frontier research" in all scientific and technological fields carried out by individual teams competing at European level; (3) Develop and strengthen the human potential of European research through the support to training, mobility and the development of European research careers (namely through the Marie Curie actions); (4) Enhance research and innovation capacity throughout Europe. The FP7 capacities programme aims to develop and fully exploit the EU's research capacities through large-scale infrastructures (including e-infrastructures such as GEANT, Grids, Supercomputing...), regional (Regions of Knowledge) and cross-border cooperation and innovating SMEs.
} 
the Enterprise Europe Network - are more of an indirect nature, not providing direct support or assistance to enterprises.

\section{German National Innovation Policy}

A comprehensive description of the German national R\&D and innovation policies is way beyond the scope of this paper. The "Pro Inno Europe" website (http://www.proinnoeurope.eu) lists currently 146 different policy schemes that support R\&D and innovation in Germany. The German federal government did not maintain an R\&D tax credit scheme during the 1990s and 2000s. The most important policy instrument for supporting innovation in the business sector is mission-oriented $\mathrm{R} \& \mathrm{D}$ and innovation funding, that is, direct project grants. In 2007, for instance, $€ 4.5$ billion were spent (see BMBF, 2010: 435). 


\section{Appendix B}

Table B1: Industries in the sample

\begin{tabular}{|c|c|c|}
\hline Industry & Description & \# of obs. in total sample \\
\hline 1 & Manufacture of food products and beverages & 287 \\
\hline 2 & Manufacture of textiles & 236 \\
\hline 3 & $\begin{array}{l}\text { Manufacture of wood and of products of wood and cork, except } \\
\text { furniture; manufacture of articles of straw and plaiting materials }\end{array}$ & 373 \\
\hline 4 & $\begin{array}{l}\text { Manufacture of coke, refined petroleum products, nuclear fuel, } \\
\text { chemicals and chemical products }\end{array}$ & 498 \\
\hline 5 & Manufacture of rubber and plastic products & 438 \\
\hline 6 & Manufacture of basic metals & 1,030 \\
\hline 7 & Manufacture of machinery and equipment n.e.c & 1,030 \\
\hline 8 & $\begin{array}{l}\text { Manufacture of radio, television and communication equipment } \\
\text { and apparatus }\end{array}$ & 1,259 \\
\hline 9 & Manufacture of motor vehicles, trailers and semi-trailers & 548 \\
\hline 10 & $\begin{array}{l}\text { Sale, maintenance and repair of motor vehicles and } \\
\text { motorcycles; retail sale of automotive fuel }\end{array}$ & 487 \\
\hline 11 & Land transport; transport via pipelines & 771 \\
\hline \multirow[t]{2}{*}{12} & Financial intermediation and real estate activities & 1,777 \\
\hline & & 8,734 \\
\hline
\end{tabular}

Table B2: Probit after matching

\begin{tabular}{cccc}
\hline Case & Number of obs & Wald $\chi 2(30)$ & p-value \\
\hline 1 & 2,796 & 11.99 & 0.999 \\
2 & 240 & 13.57 & 0.995 \\
3 & 826 & 12.4 & 0.998 \\
4 & 176 & 13.43 & 0.996 \\
5 & 884 & 18.59 & 0.948 \\
7 & 10,420 & 27.33 & 0.606 \\
10 & 6690 & 14.36 & 0.993 \\
11 & 1,816 & 17.29 & 0.969 \\
12 & 130 & 10.27 & 0.999 \\
\hline
\end{tabular}

